\title{
AusLAMP 3D MT imaging of an intracontinental deformation zone, Musgrave Province, Central Australia
}

\author{
Stephan Thiel ${ }^{1,3^{*}} \mathbb{D}$, Bruce R. Goleby ${ }^{2}$, Mark J. Pawley ${ }^{1}$ and Graham Heinson ${ }^{3}$
}

\begin{abstract}
The central Australian Musgrave Province at the junction of the South, North and West Australian cratons has undergone and continues to retain evidence of significant whole-of-crust, and most likely'whole-of-lithosphere' tectonomagmatic processes. The area is known for some of the largest geophysical anomalies related to significant Moho offsets of up to $15 \mathrm{~km}$, which resulted from repeated intracratonic reworking since the Neoproterozoic. New magnetotelluric (MT) data have been collected across the Musgrave Province in Western Australia and South Australia as part of the Australian Lithospheric Architecture Magnetotelluric Project (AusLAMP). Station spacing was $\sim 50 \mathrm{~km}$ between 96 sites over an area of $500 \times 700 \mathrm{~km}$. Long-period MT impedance and tipper data over a bandwidth of $8 \mathrm{~s}$ to 10,000 s period have been inverted using a smooth 3D inverse algorithm. The 3D model shows two predominant resistivity trends. There are deep (> $65 \mathrm{~km}$ ) north-south mantle conductors that we infer to be related to the Palaeo- to Mesoproterozoic north-trending arc-related rocks that experienced ultra-high temperature metamorphism and widespread magmatism during the Mesoproterozoic Musgravian Orogeny. These conductors are preserved in the crust south of the Musgrave Province. The upper mantle also contains a localised resistive zone that possibly represents generation of mafic- to ultramafic magmas during the c. 1090-1040 Ma Giles Event. The crust ( $<65 \mathrm{~km}$ depth) contains strong east-west crustal conductors interpreted to reflect the east-west structural grain that initiated during the $\mathrm{c}$. 1090-1040 Ma Giles Event and overprinted the older N-S-oriented mantle anomalies. These E-W crustal conductors coincide with magnetic anomalies that represent crustal-scale structures, and high gravity anomalies associated with significant Moho offsets resulting from further reactivation during the c. 630-520 Ma Petermann and c. 450-300 Ma Alice Springs orogenies.
\end{abstract}

Keywords: Magnetotelluric, AusLAMP, Musgrave Province, Intraplate deformation, Intracontinental deformation, Central Australia

\section{Introduction}

Tectonothermal events leave an imprint in the lithospheric architecture and the electrical resistivity structure measured today is a result of the cumulative fertilising and depleting effects of all events (Unsworth 2010; Selway 2014). With an increasing awareness that the rheology of the lithosphere plays an important role

\footnotetext{
*Correspondence: stephan.thiel@sa.gov.au

1 Department for Energy and Mining, Geological Survey of South

Australia, Adelaide, SA 5000, Australia

Full list of author information is available at the end of the article
}

in controlling tectonic development (Griffin et al. 2013), geophysical techniques including MT (Thiel and Heinson 2010; Duan et al. 2010; Selway et al. 2011; Thiel and Heinson 2013; Duan et al. 2013; Selway 2014; Robertson et al. 2016; Pollett et al. 2019; Wise and Thiel 2020), seismic tomography (Rawlinson et al. 2014; Kennett et al. 2013), as well as geochemical sampling of the lithospheric mantle (O'Reilly and Griffin 2010; Gaul et al. 2003) have become fundamental in imaging lithospheric structure and providing constraints on tectonic evolution. Understanding various tectono-magmatic processes of a region and their resultant orientation assists in interpreting the 
MT results in terms of identifying the cause and potential age of the various conductivity anomalies observed in the MT data. Understanding the cause of the MT response is important in interpreting the MT data as well as how this response changes over time and with successive deformation. The electrical response of rocks is usually affected by fluids, e.g. brines, pore water and by the presence of metallic or semiconductor minerals, e.g. sulphides, graphite distributed in rocks or shear zones (Hyndman and Shearer 1989; Glover 1996; Selway 2014; Pommier 2014).

The Musgrave Province in central Australia is a worthy area to evaluate the use of 3D AusLAMP MT in understanding geological processes. The Musgrave Province occurs at the junction of the North Australian, South Australian and Western Australian Cratons, and records evidence for the assembly of Proterozoic Australia. The geological history of the Musgrave Province involves c. 1650-1270 Ma magmatic arc history (Howard et al. 2015), followed by prolonged UHT conditions and magmatism during the Musgrave Orogeny (Smithies et al. 2011). Subsequent multiple overprinting with the intrusions of the giant layered mafic-ultramafic intrusions of the Giles Event (Smithies et al. 2011) and of the Warakurna Large Igneous Province (Alghamdi et al. 2018) and again localisation of deformation during the amagmatic Petermann and Alice Springs orogenies further complicates the unravelling of the Musgrave Province (Raimondo et al. 2010). The range of geological processes recognised in the Musgrave Province provides ample possibilities for leaving behind signatures of tectonomagmatic events in the lithosphere. A full 3D image of the lithosphere beneath the Musgrave Province will add an important dataset to help constrain the evolution of the Musgrave Province.

This paper presents the results of this study of the Musgrave Province and shows new lithospheric-scale 3D MT data across this intracontinental deformation zone. The paper presents a preferred interpretation of this new 3D AusLAMP MT model and describes each of the significant features observed in the 3D MT data. This interpretation is then validated against current understanding of the Musgrave Province's tectonic history, other existing MT surveys, deep seismic reflection transects of the crust and passive seismic studies of the lithosphere.

\section{Geology of the Musgrave Province}

The Musgrave Province is a Mesoproterozoic orogen exposed between the North Australian Craton (NAC), South Australian Craton (SAC), and West Australian Craton (WAC). The orogen forms a prominent easttrending gravity and magnetic anomaly located along the border between South Australia and Northern Territory, extending into Western Australia. The province comprises granulite to amphibolite facies' metamorphic rocks, intruded by granitic plutons and by mafic and ultramafic rocks, which are bound to the north and south by the Neoprotoerozoic to Paleozoic rocks of the Amadeus and Officer basins, respectively (Figs. 1, 2).

The oldest crustal component is not preserved, but is inferred from $\mathrm{Nd}$ and $\mathrm{Hf}$ isotopic studies to be c. $1950 \mathrm{Ma}$ oceanic crust that was subsequently recycled (Kirkland et al. 2017). The next stage of crustal evolution was longlived and involved the development of a series of magmatic arcs (Dutch et al. 2016; Smits et al. 2014). These include the oldest preserved rocks in the Musgrave Province, c. 1650-1600 Ma mafic to felsic volcanic and intrusive rocks, and sedimentary rocks that typically form the protolith to the Birksgate Complex in the eastern part of the province (Edgoose et al. 2004; Howard et al. 2015; Jagodzinski and Dutch 2013; Major and Conor 1993). The central part of the province contains c. 1590-1540 Ma felsic intrusive and volcanic rocks that form the protolith to the Birksgate Complex (Wade et al. 2006), although the 1607-1583 Ma Warlawurru Supersuite is exposed in the western Musgrave Province as a tectonically interleaved sliver (Howard et al. 2015; de Gromard et al. 2019). The western part of the province contains two main basement rock packages. The c. 1402 Ma Papulankutja Supersuite

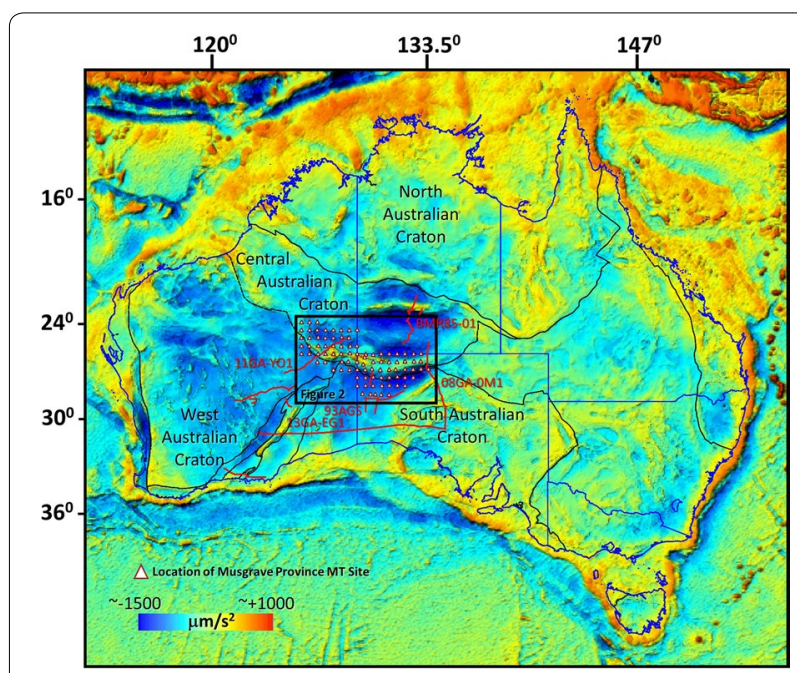

Fig. 1 Gravity image of Australia, showing the main crustal elements. The Musgrave Province is located on the boundary between the Central and South Australian Cratons. Low gravity regions are shown in blue and high gravity regions in red. The new Musgrave Province MT sites described in this study are shown as triangles. All regional deep seismic traverses intersecting the Musgrave Province are shown as red lines, with seismic line names provided for those traverses referred to later in the text. All MT profiles intersecting the Musgrave Province are coincident with deep seismic traverses. The region used for Fig. 2 is marked by the black bounding box 


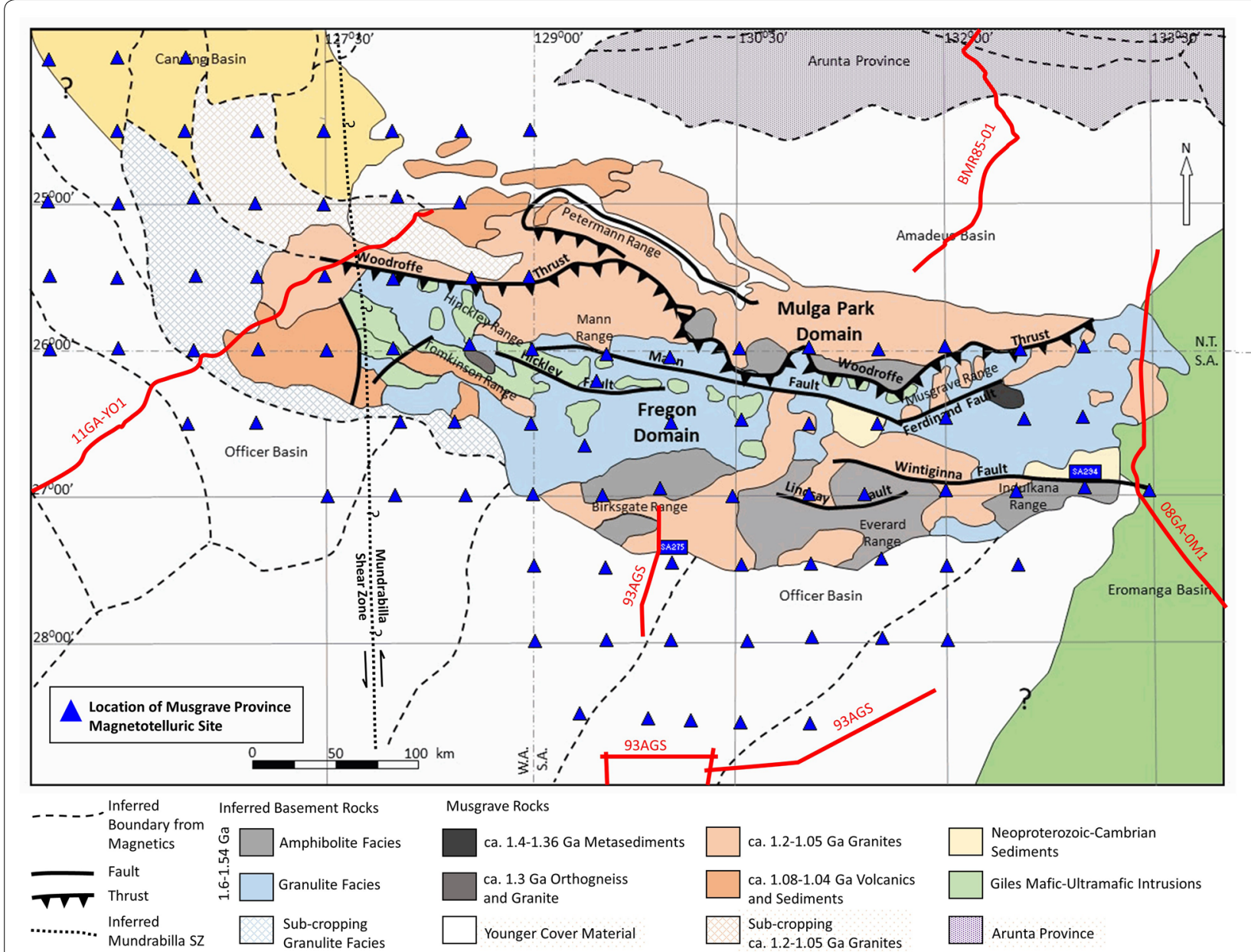

Fig. 2 Simplified geology of the outcropping Musgrave Province and subsurface structural trends inferred from interpreted magnetics and gravity. Subsurface geological trends modified after the Australian Crustal Elements Map (Geoscience Australia) and the simplified outcropping Musgrave Province from Wade et al. (2008). Musgrave Province MT site locations are shown as blue triangles. The inferred location of the Mundrabilla Shear and its northern extension is shown as a north-south dotted line (Aitken et al. 2016). State boundaries are shown for reference to Fig. 1, where NTNorthern Territory, SA — South Australia and WA-Western Australia. Regional deep seismic traverses intersecting the Musgrave Province are shown as red lines

has limited distribution and a composition consistent with an arc setting (Howard et al. 2011). The 1345-1293 Ma Wankanki Supersuite intruded during the Mount West Orogeny, with volcano-sedimentary protoliths to the 1340-1270 Ma Wirku Metamorphics deposited in a basin adjacent to the arc (Evins et al. 2012; Howard et al. 2015; Smithies et al. 2011). The Wankanki Supersuite and Mount West Orogeny are interpreted to reflect final collision of the volcanic arcs, and ultimately amalgamation of the WAC and SAC (Betts and Giles 2006; Giles et al. 2004).

The c. 1650-1270 Ma rocks have geochemical compositions consistent with volcanic arc settings (Dutch et al. 2016; Howard et al. 2015; Wade et al. 2006), and are interpreted to form a series of north-northeast-trending arcs that are young to the west (Dutch et al. 2016; Smits et al. 2014). These arcs can also be traced south into the Coompana and Madura Provinces (Dutch et al. 2016). The eastern Coompana Province contains migmatitic rocks with c. 1618-1604 Ma protoliths that have arclike compositions (Dutch 2018; Jagodzinski et al. 2018; Smithies et al. 2015c; Wingate et al. 2015a), whereas the Madura Province to the west contains c. 1415-1389 Ma metagabbros and tonalitic gneisses interpreted to form part of an oceanic arc (Smithies et al. 2015b; Wingate et al. 2015b).

The c. 1220-1150 Ma Musgrave Orogeny was widespread, affecting all of the Musgrave Province (Edgoose et al. 2004; Major and Conor 1993; Smithies et al. 2011). Deformation resulted in widespread upright 
north-northeast-trending isoclinal to tight folding, and a steeply dipping north- to northeast-trending migmatitic layering, which forms a grain that is prominent on the aeromagnetic images (Aitken and Betts 2008; Edgoose et al. 2004; Pawley et al. 2014; Wade et al. 2008). These observations suggest that the orogen was undergoing southeast-northwest-directed shortening. This steep fabric, however, is a relatively late feature, with parts of the eastern Musgrave Province preserving evidence for east-west-directed extension during the early Musgrave Orogeny (Pawley et al. 2016). Magmatism was widespread, including the voluminous mantle-derived granitic magmas of the 1220-1140 Ma Pitjantjatjara Supersuite, and was accompanied by prolonged ultra-high temperature crustal conditions (Edgoose et al. 2004; Jagodzinski and Dutch 2013; Smithies et al. 2011, 2015a). Smithies et al. (2011) proposed that the extensive magmatism was triggered by the remobilisation of lower crustal MASH zones where mantle-derived mafic magmas assimilated felsic crust. The ultra-high temperature conditions were generated during intracontinental extension, when asthenospheric upwelling was focussed and fixed between the WAC, SAC and NAC. Gorczyk and Vogt (2015) proposed that the prolonged high temperature could also be due to delamination of post-subduction mantle lithosphere following the Mount West Orogeny.

There is evidence that the Musgrave Orogeny forms part of a larger tectono-magmatic event. Aitken and Betts (2008) recognised a northeast-trending magnetic grain in the basement beneath the Amadeus and Officer basins. This grain was interpreted to represent chains of Pitjantjatjara Supersuite granite plutons that can be traced back to the Musgrave Province. Spaggiari et al. (2016) proposed the Maralinga Event, which produced magmas with similar ages and compositions to the Pitjantjatjara Supersuite in the Albany-Fraser Orogen and Madura and Coompana provinces to the south of the Musgrave Province (Clark et al. 2000; Dutch 2018; Jagodzinski et al. 2018; Smithies et al. 2015b; Wingate et al. 2015a). North of the Musgrave Province, the southern margin of the North Australian Craton was undergoing north-southdirected shortening at c. $1130 \mathrm{Ma}$ that was interpreted to record convergence of the North Australian Craton with the Musgrave Province (Wong et al. 2015).

The 1090-1040 Ma Giles Event followed the Musgrave Orogeny, and can be recognised across the Musgrave Province (Smithies et al. 2015d). The Giles Event is the dominant rock package in the western Musgrave Province, where intracontinental rift-related mafic-felsic volcanic and sedimentary rocks (including supervolcanoes), and giant layered mafic-ultramafic intrusions, gabbros, dolerites and leucogranites are preserved (Evins et al. 2010; Howard et al. 2015; Smithies et al. 2015a, d). The central Musgrave Province contains large layered mafic intrusions, granite plutons and Alcurra Dolerite dykes, which generally appear to reduce in size and number towards the east (Edgoose et al. 2004; Major and Conor 1993). In the eastern Musgrave Province, the Giles Event is represented by east-trending dykes of Alcurra Dolerite, which form the Kulgera dyke swarm (Camacho et al. 1991; Werner et al. 2014). The Giles event was accompanied by deformation, with evidence for normal faulting, or fault reactivation. These structures range from northwest-striking in the west (including the Ngaanyatjarra Rift) to east-striking in the central and eastern parts of the province (Evins et al. 2010; Pawley et al. 2014; de Gromard et al. 2019).

Smithies et al. (2015a) proposed that the Giles Event was triggered when intraplate movement along the north-trending, crustal-scale Mundrabilla Shear Zone, displaced and destabilised the thermal anomaly underlying the Musgrave Province. Magmatism was particularly focussed at the intersection of these two features, producing the voluminous magmatism in the western Musgrave Province. Rocks of the Giles Event can be traced south of the Musgrave Province into the Coompana Province, where a series of circular remanently magnetised bodies can be recognised on the aeromagnetic data. These bodies form a chain that can be traced down the eastern side of the Mundrabilla Shear Zone for $\sim 300 \mathrm{~km}$, before turning to the southeast for $\sim 300 \mathrm{~km}$ (Pawley et al. 2018).

The c. 825-760 Ma Amata Dolerite forms widespread northwest-trending dykes in the eastern Musgrave Province (Glikson et al. 1996; Werner et al. 2018). These rocks form part of the Gairdner-Willoran-Guibei Large Igneous Province that resulted from plume activity, centred to the southeast of the present Musgrave Province during early rifting stages of Rodinia (Werner et al. 2018; Wingate et al. 1998; Zhao et al. 1994). This period of magmatism was followed by thermal recovery and subsidence as plume activity declined, leading to broad crustal sagging and the onset of sedimentation within the Centralian Superbasin that covered most of central and southern Australia (Lindsay 2002; Walter et al. 1995). Sedimentation was terminated by the Petermann Orogeny, which caused local uplift of the basement to dismember the Centralian Superbasin into a series of basins, including the Amadeus and Officer basins that are now separated by the upthrust Musgrave Orogen (Lindsay and Leven 1996).

The c. 630-520 Ma Petermann Orogeny involved intracontinental reactivation (Camacho and Fanning 1995; Major and Conor 1993; de Gromard et al. 2019; Sandiford and Hand 1998). The earliest phase of deformation (c. $630 \mathrm{Ma}$ ) was recognised in the western 
Musgrave Province where east-west-shortening resulted in north-trending folds and thrust system (de Gromard et al. 2019). However, the Petermann Orogeny generally appears to have involved north-directed shortening, which resulted in uplift and thrusting of the Musgrave Region over the Amadeus and Officer basins (Edgoose et al. 2004; Flöttmann et al. 2004; Sandiford and Hand 1998). Uplift of the core of the orogeny was accommodated by diverging thrusts, including the north-dipping Everard Thrust located along the southern margin of the province, and the south-dipping Woodroffe Thrust in the north (Camacho and McDougall 2000; Edgoose et al. 2004; Flöttmann et al. 2004; Major and Conor 1993). The Woodroffe Thrust juxtaposed transitional granulite facies' rocks of the Fregon Domain to the south against low to medium pressure amphibolite facies' rocks in the Mulga Park Domain to the north, with grade reducing northwards (Camacho and Fanning 1995; Raimondo et al. 2010; Scrimgeour and Close 1999). Seismic studies have shown the two thrusts to be crustal-scale structures that offset the Moho (Korsch and Kositcin 2010; Lambeck and Burgess 1992). The Petermann Orogeny also produced, and reactivated, steep predominantly strike-slip faults within the core of the province (Aitken et al. 2009; Major and Conor 1993; Pawley et al. 2014; de Gromard et al. 2019). These include the Mann Fault in the central Musgrave Province, and the Echo-De RoseWintinginna fault system that bounds the dextral, strikeslip pull-apart Moorilyanna Graben in the eastern part of the province (Gravestock et al. 1995; Korsch and Kositcin 2010).

The c. 450-300 Ma Alice Springs Orogeny was focussed north of the Musgrave Province, where it was responsible for deformation and uplift of the Arunta Province (Collins and Shaw 1995; Mawby et al. 1999). However, there is also evidence for north-south-directed shortening in the Musgrave Province at this time (Edgoose et al. 2004; Hand and Sandiford 1999; Lindsay and Leven 1996). Internal east-trending structures were reactivated across large parts of the province, including the Woodroffe Thrust, and the Marryat and Coglin faults in the eastern Musgrave Province (Glorie et al. 2017; de Gromard et al. 2019). There is also evidence for reactivation of the southern margin of the Musgrave Province at the contact with the Officer Basin (Hand and Sandiford 1999; Lindsay and Leven 1996; Drexel et al. 1993).

\section{Lithospheric structure of the Musgrave Province}

The lithosphere, comprising the crust and uppermost solid mantle, varies between 180 and $240 \mathrm{~km}$ in thickness across the Musgrave Province (Fishwick and Reading 2008; Fichtner et al. 2010; Kennett et al. 2013). Teleseismic tomography and receiver function studies show the Musgrave Province is underlain by $40 \mathrm{~km}$ to $50 \mathrm{~km}$ thick crust and a mainly transitional Moho, similar in thickness to both the North Australian and South Australian Cratons (Lambeck and Burgess 1992; Salmon et al. 2013; Clitheroe et al. 2000). Seismic reflection and 2D gravity forward modelling also show that the regions' gravity anomalies coincide with significant Moho offsets, suggestive of 'thick-skinned' deformation (Goleby et al. 1989), resulting from the lower crustal response to the Palaeozoic deformation during the Petermann Orogeny (Aitken et al. 2009). The velocity models also image significant heterogeneity within the Musgrave Province down to $200 \mathrm{~km}$ (Fichtner et al. 2010; Kennett et al. 2013).

Ambient noise studies were used to map the upper and middle crust to depths of around $30 \mathrm{~km}$ (Saygin and Kennett 2010). The authors concluded that Rayleigh wave velocities as low as $2.0 \mathrm{~km} \cdot \mathrm{s}^{-1}$ are due to crustal composition and the presence of high thermal gradients in the Musgrave and Arunta Provinces.

Deep seismic reflection studies over the region are limited to four transects, all at the margins of the Musgrave Province (Fig. 1). The two oldest seismic surveys do not directly cross the Musgrave Province but identified significant Moho offsets in Central Australia which share a similar tectonic history in the Phanerozoic (profiles BMR85 and 93AGS in Fig. 1) (Goleby et al. 1988; Korsch et al. 1998). The 2011 Yilgarn-Officer-Musgrave survey (11GA-YO1; Fig. 1) crosses the Musgrave Province's south-western boundary and heads northeast into the centre of the Musgrave Province (Howard et al. 2011; Neumann 2013). The 2008 Gawler-Officer-Musgrave-Amadeus (GOMA) survey crosses the Musgrave Province's south-eastern boundary and extends into the centre of the Musgrave Province (Korsch and Kositcin 2010). The 2013 and 2008 surveys both imaged southdipping crustal-scale structures.

Previous MT studies of the Musgrave Province proper are either scattered individual conductivity profiles or 2D MT surveys acquired coincident with the deep seismic traverses. The $2 \mathrm{D}$ profiles relevant to the current MT investigation are the Yilgarn-Officer-Musgrave MT (YOM MT) survey, which is coincident with the deep seismic traverse 13GA-YO1 (Fig. 1) and crosses the south-western margin of Musgrave Province and images the western-most portion of the Musgrave Province (Duan et al. 2013; Aitken et al. 2013). Second, the GOMA MT survey (Duan et al. 2010; Selway et al. 2011) which is also coincident with the 08GA-OM1 deep seismic traverse (Fig. 1) runs north-south through the eastern-most Musgrave Province. Both MT profiles identified good 2D structures including significant south-dipping structures 
in the resistivity model that approximate the location of the Woodroffe Thrust.

Pollett et al. (2019), after remodelling the GOMA MT Survey data and extending it to the north, argue that the transition from Musgrave Province lithosphere to Gawler Craton lithosphere can be imaged through significant changes in heat flow and electrical conductivity, with the respective contrasts strong enough to constrain this boundary more accurately than previous geophysical models.

A third 2D MT transect that is useful in understanding the regions' lithospheric structure is MT profiles 12GAAF3 and 13GA-EG1 (Wise and Thiel 2020; Spratt et al. 2014). These two MT profiles link, are located south of the Musgrave Province, and run east-west from the edge of the Yilgarn Craton, eastwards across the Albany-Fraser Orogen, the Madura and Coompana Provinces, eastwards to the northern part of the Fowler Domain and central Gawler Craton (Wise and Thiel 2020; Spratt et al. 2014). Together these two profiles highlight an extensive lower crustal to upper mantle conductor spanning the entire Eucla and Coompana Province. The conductor appears to cut through the interpreted extent of the subvertical Mundrabilla Shear Zone derived from seismic reflection data and coincides with a low-reflectivity zone in the co-located seismic reflection profile (Wise and
Thiel 2020). Following its subdued response in the MT data, the 2D inversion of the profile also does not show a clear sub-vertical feature associated with the Mundrabilla Shear Zone.

\section{The Musgrave Province AusLAMP experiment}

Data were collected as part of the larger AusLAMP project, creating a continuous MT data coverage across South Australia and eventually the whole of Australia. The area covered by this survey incorporates Ngaanyatjarra Lands in Western Australia and the Anangu Pitjantjatjara Yankunytjatjara (APY) Lands in South Australia (Fig. 3). This survey recorded long-period (50 s to 10,000 s) MT data spaced approximately every half degree latitude and longitude (about $55 \mathrm{~km}$ at mid latitudes) to record the resistivity of the crust and upper mantle to improve the understanding of the structure of the lithosphere.

Instruments were predominantly from the ANSIR/ AuScope National MT long-period instrument pool consisting of 6 channel Earth Data Recording Instruments (Model-PR6-24), Bartington 3-component Fluxgate Magnetometers (Model Mag03MS70, 70 nano Tesla, $0-3 \mathrm{kHz}$ ) and unpolarisable $\mathrm{Pb}-\mathrm{PbCl}$ electrodes (Model -PMS9000, SDEC, France). These instruments were deployed for around 3 weeks to ensure data to 10,000

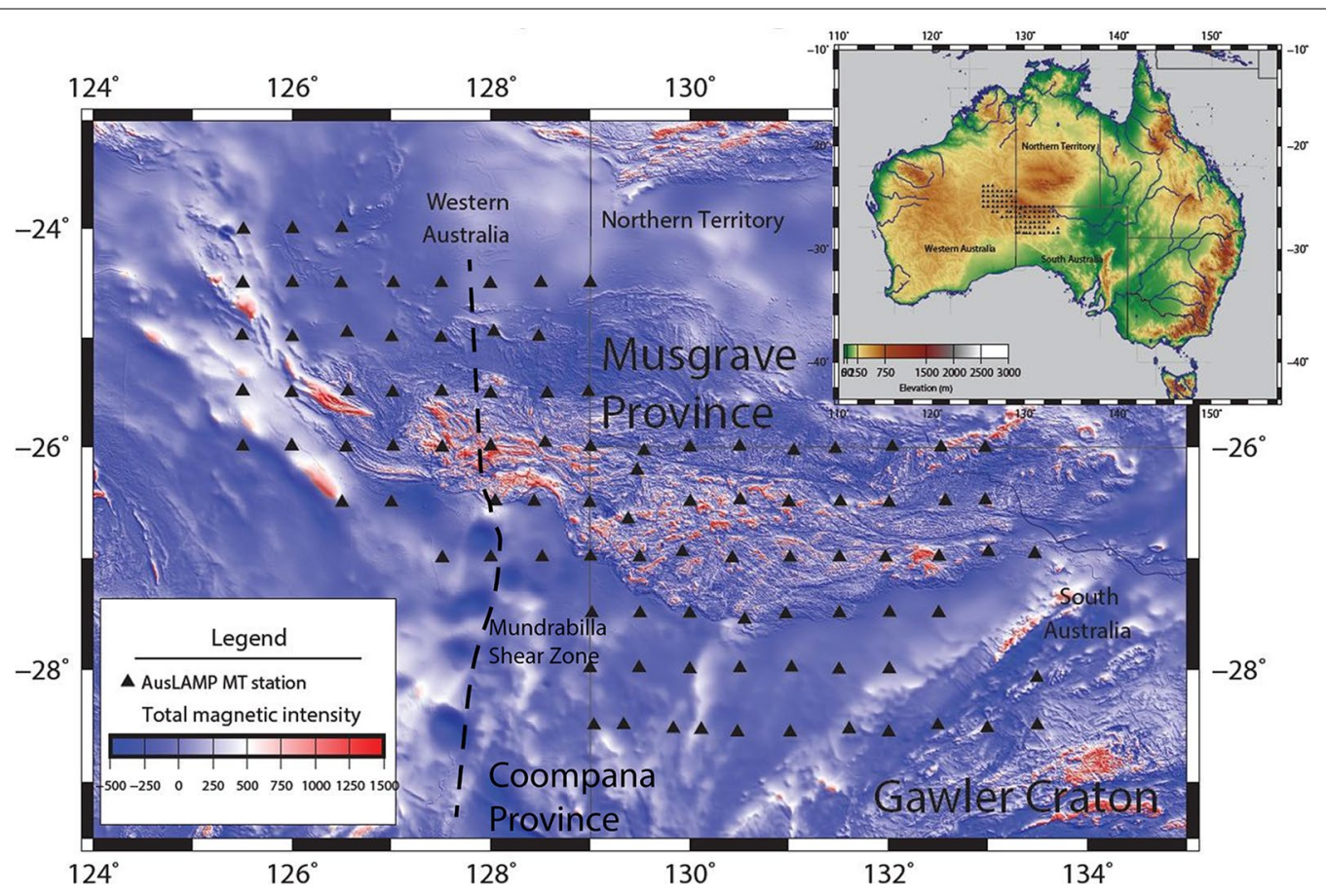

Fig. 3 Map of the central Australian region showing total magnetic intensity over the Musgrave Province with the location of the Musgrave Province MT sites superimposed as black triangles. Inset is Australian relief image with MT sites superimposed to show geographic coverage with respect to the Australia continent. The Mundrabilla Shear Zone is shown as a dashed line (Aitken et al. 2016) 
$\mathrm{s}$ were recorded. As the survey area was so remote and financial costs to get to the survey area were high, before retrieval of each unit, the data were analysed on site to ensure it was of suitable quality.

Data collected throughout the Musgrave Province are generally of very high quality with smooth impedance and tipper responses between $5 \mathrm{~s}$ and over 10,000 s. During collection, continuous time series were produced for the individual $E_{x}, E_{y}, B_{x}, B_{y}$ and $B_{z}$ signal, where $x$ referred to the North direction, $y$ referred to East direction and $\mathrm{z}$ the vertical direction. Time series were converted to impedances using the BIRRP robust processing code (Chave and Thomson 2004). These time series were inspected to ensure the signal was of sufficiently high quality to meet the objectives of the survey. An example of two MT time series is shown in Fig. 4. Figure 5 shows a plot of five representative MT responses: the data quality for the array is excellent throughout with longest periods exceeding 10,000-s period at almost every site. The responses generally divide into two sub-groups, representing low apparent resistivities for stations across the sedimentary basins surrounding the Musgrave Province, and the continuously high apparent resistivities for stations across the Musgrave Province.

Figure 6 is a composite image showing phase tensors and induction arrows at periods of $50 \mathrm{~s}, 500 \mathrm{~s}$ and 4000 $\mathrm{s}$ to show variation in spatial and depth dependence of resistivity, confirming that $3 \mathrm{D}$ induction is at a Province scale. The relative rotation of the phase tensors indicates the Musgrave Province has a strong three-dimensionality at depth. For the phase tensors, the southern margin of the Musgrave Province is clearly seen as an arcuate structure; the boundary trending east-west in the south east and south, then bending northwards at the western side of the model.

Induction arrows show a first-order resistive nature of the Musgrave Province compared to its margins (Fig. 6), particularly in the south and southwest. Induction arrows at all periods have a larger magnitude with a predominant orientation towards the arcuate southern margin of the Musgrave Province. This suggests a significant change in resistivity contrast from resistive Musgrave Province

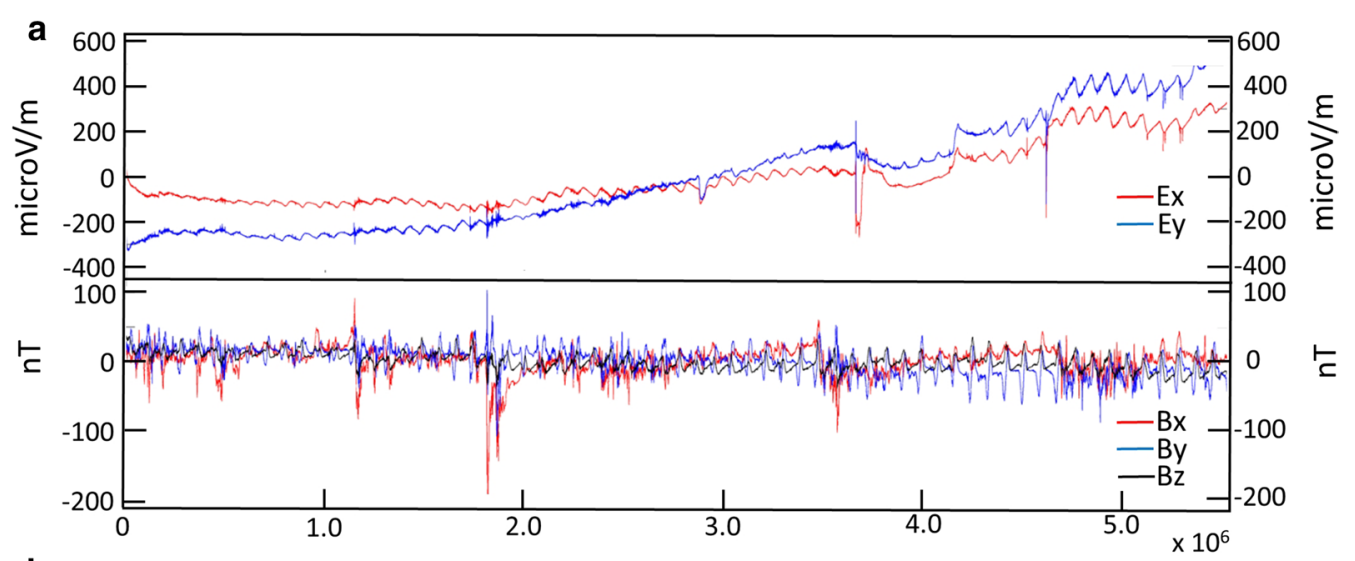

\section{b}

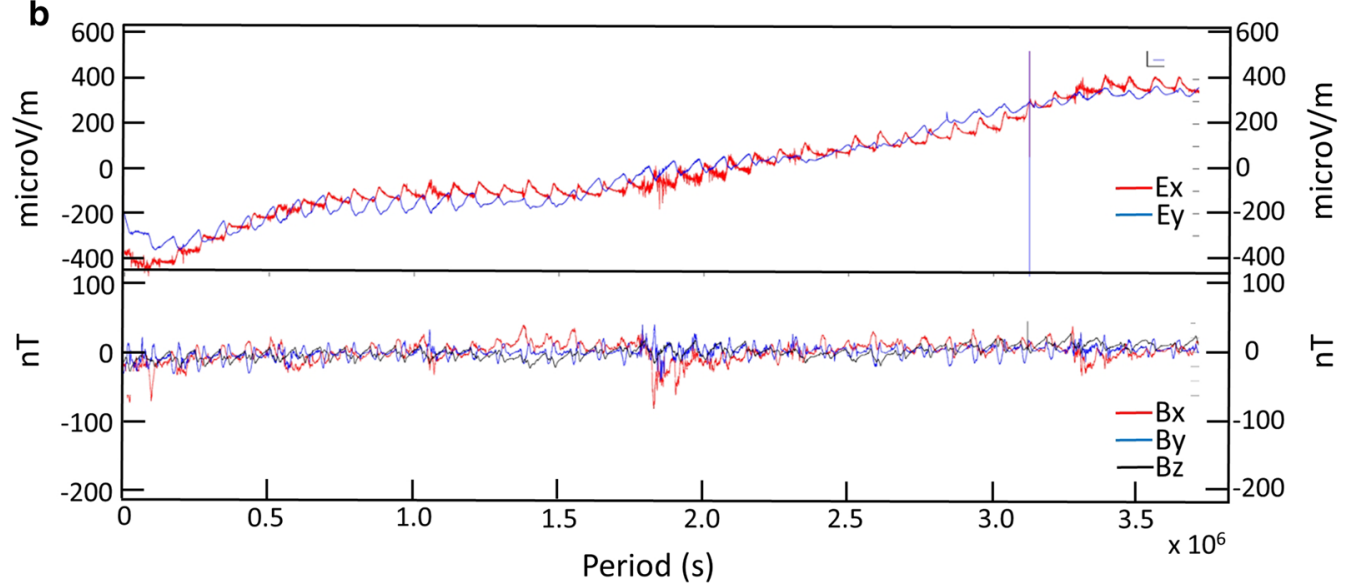

Fig. 4 Concatenated MT time series for a site SA275 and $\mathbf{b}$ site SA294. These time series plots illustrate the data quality recorded. The plots show strong diurnal signal variation as well as several periods of strong geomagnetic activity 


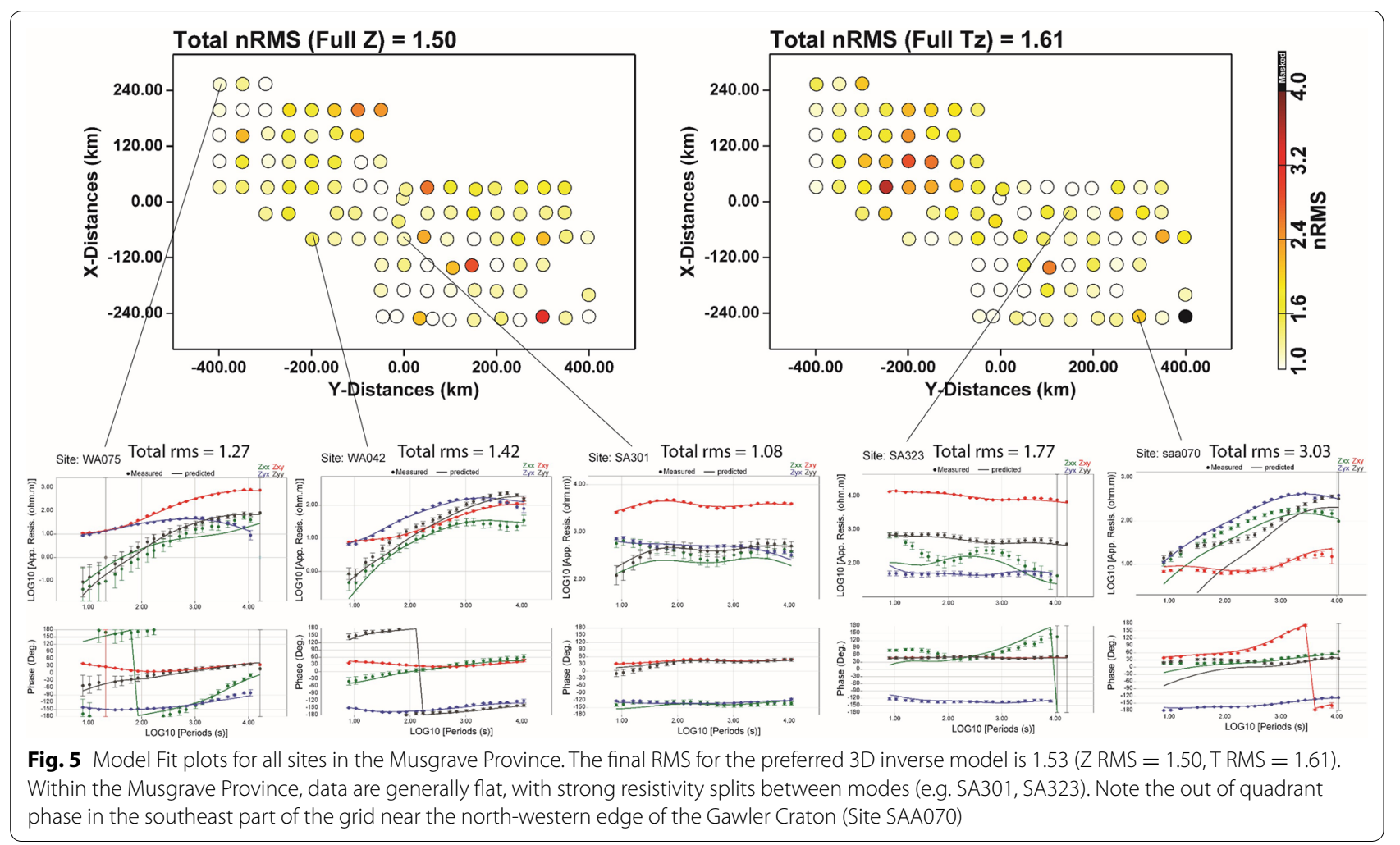

to the more conductive southern margin and the Officer Basin sediments.

\section{Results}

\section{Inversion parameters}

The MT data were inverted using ModEM (Egbert and Kelbert 2012; Kelbert et al. 2014). Data were initially edited to omit noisy soundings with large scatter or large error bars, but given the overall data quality little editing was required. The ModEM input data consisted of both full impedance and vertical magnetic transfer functions. The 96 MT stations were inverted using 23 periods for Z over the range 8 to $16,000 \mathrm{~s}$ (error floors of $3 \%$ and $10 \%$ for the off-diagonal and diagonal impedance tensor elements, respectively) and 21 periods for the vertical field transfer functions over the range 8 to $7000 \mathrm{~s}$ (error floor of 0.03).

Grid-cell dimensions were 6 by $6 \mathrm{~km}$ in the horizontal north and east directions for the inner grid, with 15 padding cells added each side surrounding the internal model, increasing by a factor 1.5 at each horizontal direction increment. The vertical grid started at $50 \mathrm{~m}$ cell thickness beneath the surface and increased by factor 1.11 to a final depth of $2131 \mathrm{~km}$. This resulted in a model size of $2517 \mathrm{~km} \times 2805 \mathrm{~km} \times 2131 \mathrm{~km}$ with $115 \times 163 \times 81$ cells in the $x_{-}, y_{-}, z_{\text {-directions respectively. A } 100 \Omega \mathrm{m}}$ starting half-space was used, and bathymetry $(0.3 \Omega \mathrm{m}$ sea resistivity) and ocean sediments were included as the margins of the model covered to the coastline. A number of different inversions were undertaken, varying covariance and smoothness parameters and for each, to test model fit and sensitivity of model features (Robertson et al. 2020). The best fitting model was achieved using a covariance of 0.4 and the smoothness applied once. Other inversions included a covariance of 0.3 , as well as smoothing applied twice for a covariance of 0.3 and 0.4 .

The resulting model misfit analysis (Fig. 5) shows the MT data across the Musgrave Province are consistently fit with RMS values commonly less than 2 . The final RMS for the preferred 3D inverse model, with a covariance of 0.4 and the smoothness applied once, is 1.53 ( $\mathrm{Z}$ normalised $\mathrm{RMS}=1.50, \mathrm{~T}$ normalised RMS $=1.61$ ). The MT response of stations surrounding the Musgrave Province is dominated by sediments with an increase in apparent resistivities towards longer periods surrounding the Musgrave Province. Within the Musgrave Province, data for the principal components $Z_{x y}$ and $Z_{y x}$ of the impedance tensor show relatively constant apparent resistivities over the entire period range, suggestive of a predominantly resistive crust and upper mantle. The splits in the apparent resistivity curves suggest some directional distortion in the data, yet these are retrievable in the 3D inversion.

Site SAA070 (Fig. 5) has phase out-of-quadrant in the southeast part of the grid, near the northwest edge of the 


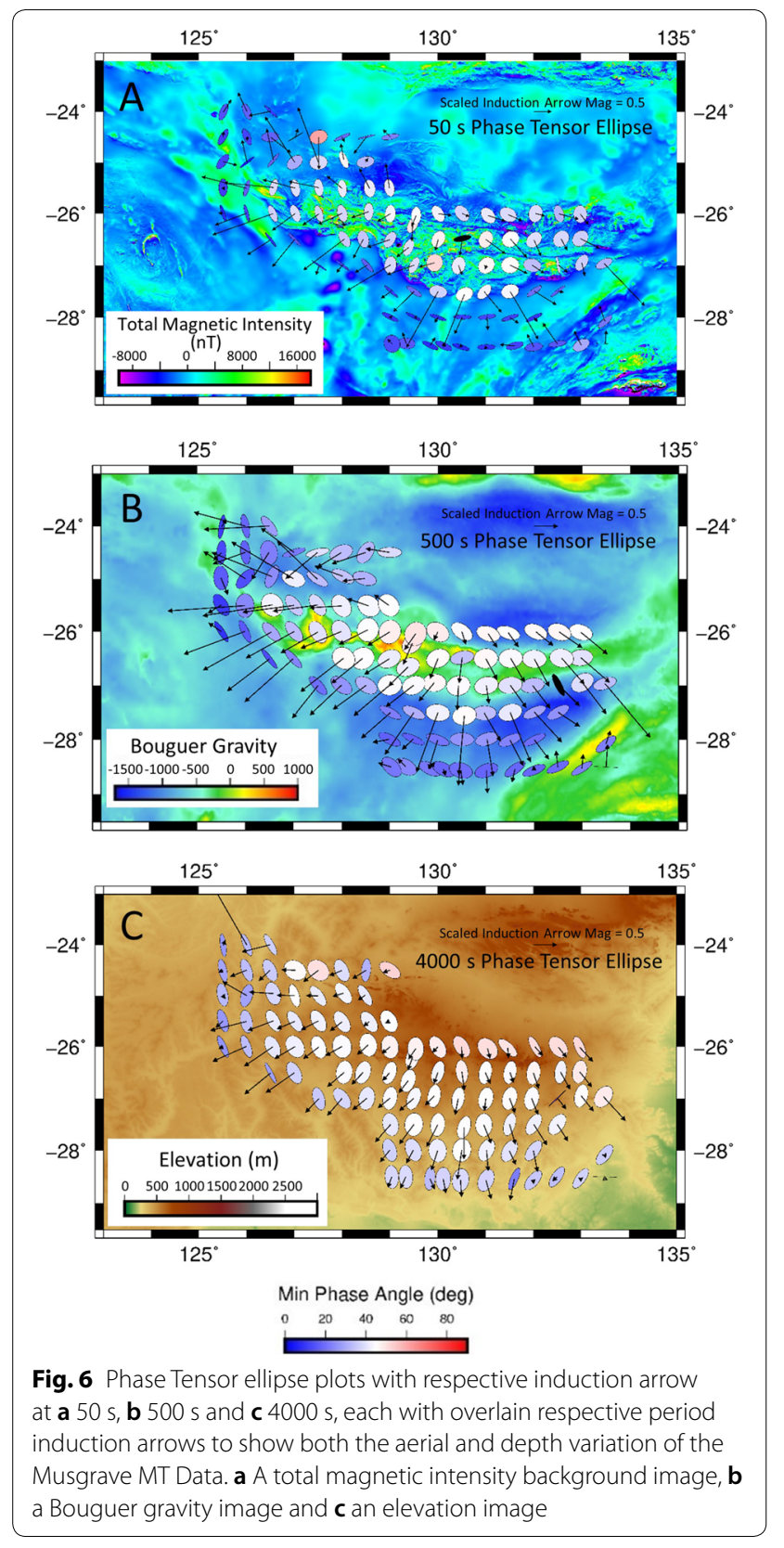

Gawler Craton. This is likely indicative of current channelling at the confluence of the margins of the Musgrave Province and the Gawler Craton to the southeast. Whilst the RMS for this site is higher at RMS $=4.08$, the inversion model is able to fit the phases out of quadrant.

\section{The 3D AusLAMP resistivity model of the Musgrave Province}

The 3D MT electrical responses presented herein reflect variations in either the electrical characteristics of the various rock types present within the crust and the mantle beneath the Musgrave Province or the structures superimposed on these rocks during tectonic events (e.g. metamorphism, partial melting, stress) (Selway et al. 2014; Thiel et al. 2016b; Wise and Thiel 2020). Equally, shearing or faulting a rock can also significantly change the electrical properties (Jones et al. 2005) through increased fluid flow through these new pathways and associated recrystallisation within these zones; meaning some of the 3D MT electrical response images also represent structural features. The 3D MT electrical responses are therefore a mix of both geological/lithological variations as well as structural features.

The preferred 3D resistivity model is shown in Fig. 7, with depth slices at $10 \mathrm{~km}, 20 \mathrm{~km}, 30 \mathrm{~km}, 38 \mathrm{~km}, 65 \mathrm{~km}$ and $100 \mathrm{~km}$. Several trends can be recognised in this model. The crustal depth slices $(10 \mathrm{~km}, 20 \mathrm{~km}$, and 30 $\mathrm{km}$ and in-between) show a strong east-west trend, parallel to the gravity highs and restricted to the Musgrave Province (Fig. 7a-d). In the lower crustal levels, a northsouth trend can be seen south of the Musgrave Province in the Coompana Province (Fig. 7c, d). The location of the Mundrabilla Shear Zone is plotted in Fig. 7c, but is not a prominent electrically defined structure but a nonconductive reactivated zone. The deeper depth slices (65 $\mathrm{km}$ and $100 \mathrm{~km}$ and in-between) show a predominant north-northeast trend in electrical response, which can generally be traced across the Musgrave Province and into the adjacent regions (Fig. 7e, f). To the west of the survey area, the lithosphere is generally resistive reflecting the depleted Yilgarn Craton; however, resolution is limited due to the station coverage mostly centred across the Musgrave Province.

A series of east-west cross-sections were made through the preferred 3D resistivity model, and show a range of features that vary across the region (Fig. 8). The northern two sections (Fig. 8a, b), which cross the northwestern Musgrave Province, show several features that appear to be influenced by the location of the Mundrabilla Shear Zone. The upper crust is highly conductive, and would correspond to the sediments of the Amadeus Basin to the north, and Phanerozoic Canning Basin to the northwest (Fig. 2). The lower crust immediately to the east of the Mundrabilla Shear Zone is highly conductive and overlain by restive middle to upper crust, which is best observed in Fig. 8b. The upper mantle is generally resistive in this area. West of the Mundrabilla Shear Zone, there is a large, moderately conductive zone in the upper mantle that is $\sim 100 \mathrm{~km}$ wide and deeper than 100 $\mathrm{km}$. Fig. 8b shows a narrow conductive corridor that can be traced from the deeper conductive zone up into the crust. In plan view, the narrow corridor forms a small discrete (pipe-like) conductive zone that can be seen on all depth slices of the 3D resistivity model (Fig. 7). 


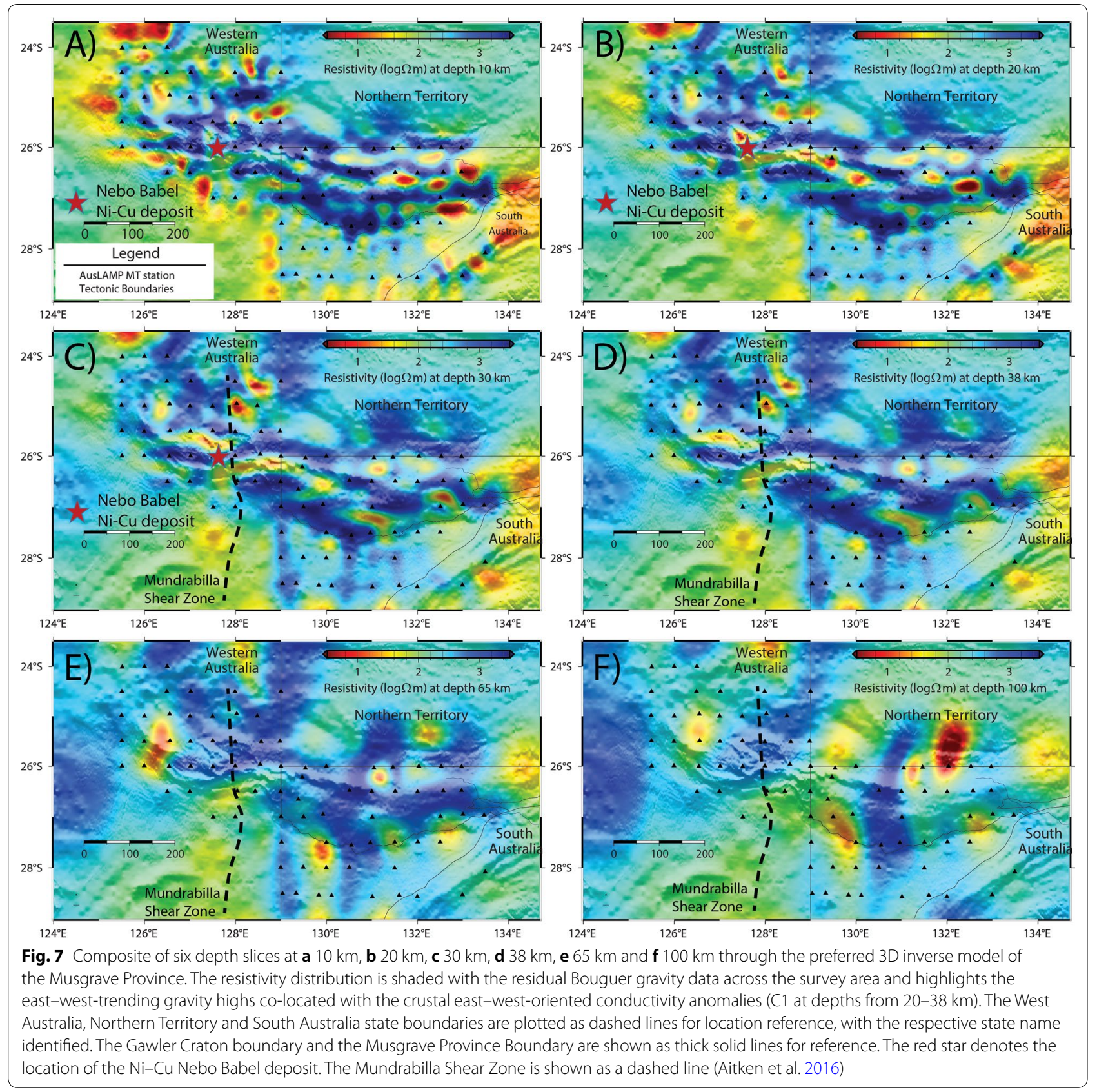

The three east-west cross-sections through the Musgrave Orogen (i.e. Fig. 8c-e) show a series of higher resistivity areas in the crust that may represent more mafic/ ultramafic material that has been thrust upwards. The three sections are also characterised by a series of moderately conductive anomalies in the upper mantle that occur generally between 80 to $120 \mathrm{~km}$ depth, but rise towards the surface in the west, where it corresponds to the southwestern margin of the Musgrave Province. In all three of the cross-sections, the conductivity anomalies are intercalated by more resistive zones under the central Musgrave Province, which correspond to upper manthe north-northeast-trending resistive zones in the $3 \mathrm{D}$ resistivity model (Fig. 7e, f). The resistive zone is generally steep, although there is an inclined (apparently eastdipping) moderately conductive zone in the cross-section across the southern part of the province. Overall, this suggests that the crust and upper mantle beneath the Musgrave Province can be divided into several electrically different regions. The resistive mantle lithosphere 


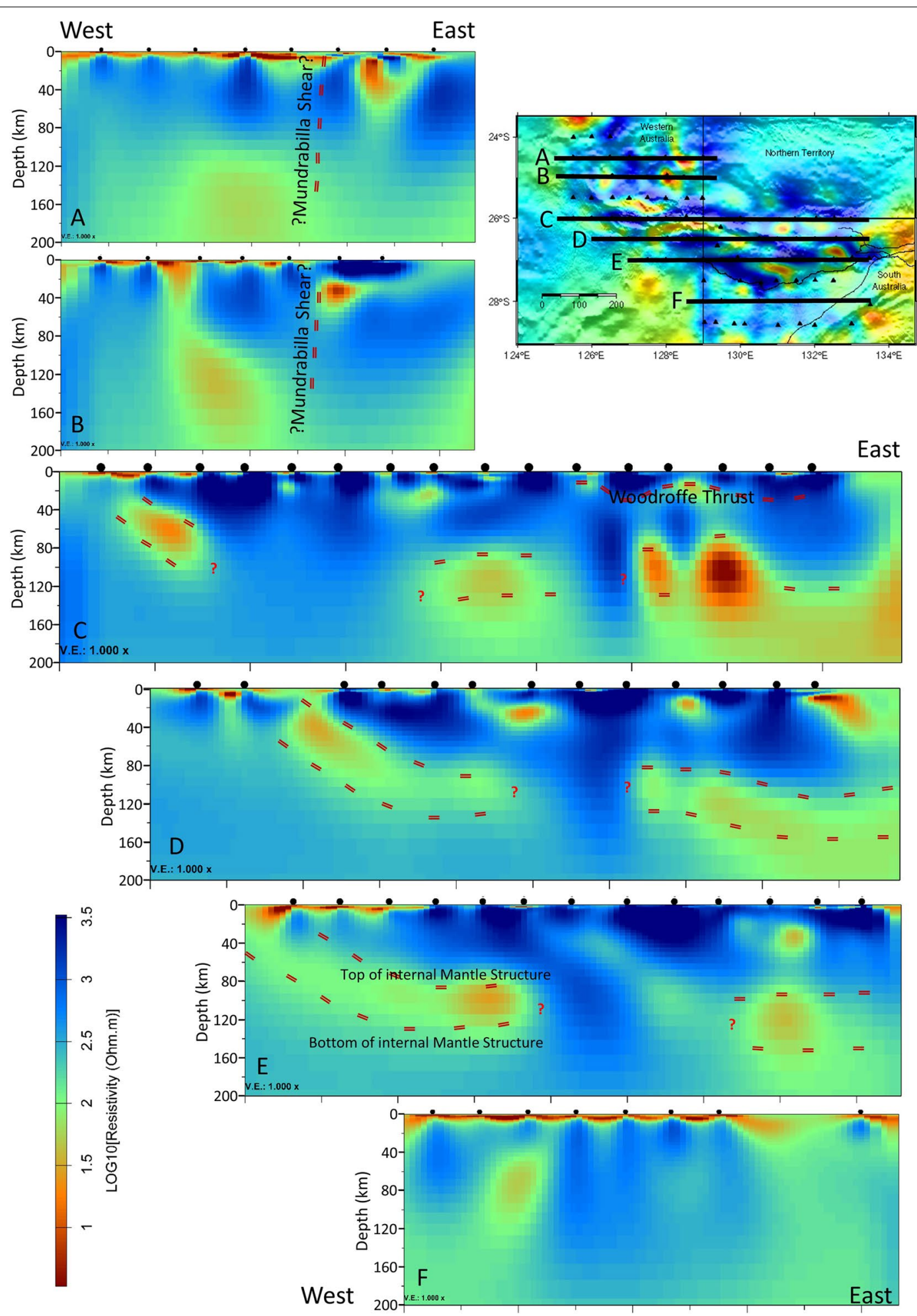

Fig. 8 Composite of six east-west cross-sections through the preferred 3D inverse model of the Musgrave Province. The inferred positions of the Mundrabilla Shear and Woodroofe Shear are shown (Aitken et al. 2016). The red dashed trend lines bound a large layered mantle structure that gently deepens southwards. The Western Australia, Northern Territory and South Australia state boundaries are plotted on the inset map for location reference 
under the western Musgrave Province in Fig. $8 \mathrm{c}$ is in an area that corresponds to the focus of Giles Event magmatism. The moderately resistive mantle is not seen in the model to the south, suggesting this resistive zone does not continue further south. To the north, the resistive zone continues to the north-northeast in the 3D resistivity model below $65 \mathrm{~km}$ depth, and also to the northnorthwest in the $65 \mathrm{~km}$ depth slice (Fig. 7e, f).

The southernmost east-west cross-section (Fig. 8f) is located south of the Musgrave Province and shows two main features. First, the uppermost part of the crust, which corresponds to the thick sediments of the Officer Basin, is highly conductive. Second, the upper mantle is characterised by zones of moderately conductive and resistive material, with the resistive zone corresponding to the upper mantle north-northeast-trending resistive zone (Fig. 7e, f) that can also be seen in Fig. 8c-e.

Seven north-south cross-sections through the model were made, with the intention of traversing the eastwest-trending grain observed in the crust on potential field images. All sections show highly conductive upper crust to the north and south of the Musgrave Province, which would correspond to the sedimentary rocks of the Amadeus and Officer basins, respectively.

The crust of the Musgrave Province contains a series of conductive $(<50 \Omega \mathrm{m})$ anomalies between $10 \mathrm{~km}$ and 40 $\mathrm{km}$ width that can be traced between the cross-sections (Fig. 9) indicating they form approximately east-westtrending features, similar to that seen on the 3D resistivity model (Fig. $7 \mathrm{a}-\mathrm{d}$ ). The boundaries of the east-west conductors correspond to the major shears and faults that are seen in the geology and potential field images. The Woodroffe and Everard thrusts are particularly prominent, with the latter structure defined at the surface by the edge of the highly conductive Officer Basin to the south (e.g. Fig. $9 d-f)$. The core of the orogen is characterised by a conductive zone (e.g. Figs. $7 \mathrm{a}, \mathrm{b}, 9 \mathrm{~d}-\mathrm{g}$ ), which can be traced down into the upper mantle in the two easternmost cross-sections where it links with the conductive upper mantle to the north of the Musgrave Province (i.e. Fig. $9 \mathrm{f}-\mathrm{g}$ ).

The upper mantle to the north and under the northern Musgrave Province tends to be variably conductive (e.g. Fig. 9 f-g), which is controlled by the location of the section lines relative to the north-northeast-striking electrical banding in the deeper levels of the model (Fig. 7e, $\mathrm{f})$. There is weak doming of moderately conductive $(<100 \Omega \mathrm{m})$ material in the lithosphere beneath the Musgrave Province within the 3D model that is associated with offsets in the upper crust (marked X in E-W profile D of Fig. 9).

It is likely that anisotropy may play a role in the inversion and interpretation of our preferred model of the
Musgrave Province. Meqbel et al. (2014) showed that the elongated streaks that are about the same width as the station spacing at lower crustal and upper mantle depths $(30-60 \mathrm{~km})$ are probably not structures, but rather an expression of anisotropy in an inversion that does not solve for anisotropy. 3D inversions of the USArray MT program across the continental US observed elongated conductivity anomalies at Moho and upper mantle depths $(30-60 \mathrm{~km})$ with a characteristic width equal to their depth (Meqbel et al. 2014). Importantly for the Musgrave Province MT data discussed herein, the USArray MT data are comparable to the presented Musgrave Province MT data in that it has similar station spacing and therefore we might expect to see elongated streaks in the data that are about the same width as the station spacing. Meqbel et al. (2014) supported their observation by comparing with the fast axis of an SKS split study and show that both the seismic and the electrical fast axis point in the same direction. The preferred Musgrave Province MT model presented herein does show features that could be related to anisotropy, i.e. with structures showing elongated features similar in scale to the station spacing. Phase tensors and induction arrows inherently cannot uniquely resolve the presence of anisotropy, i.e. through phase splits (Heise et al. 2006). Whilst anisotropy is principally an explanation that needs to be considered, the cross-correlation of the E-W-trending gravity highs and the spatial changes in orientation of the phase tensor major axes and of the induction arrows across the array (Fig. 6) make anisotropy an unlikely cause for the conductors around the Moho depth. A more likely candidate may be the NNE orientation of conductors deeper in the lithosphere at depths greater than $100 \mathrm{~km}$ in our models. The alignment of the phase tensors is more homogeneous for very long periods of a few thousand seconds.

\section{Discussion}

These new MT data provide information of the resistivity structure of the crust and upper mantle beneath the Musgrave Province, and provide constraints on the tectonic evolution of the Musgrave Province. Whilst the Musgrave Province shows a complex history of tectono-magmatic events that successively overprint each other, our approach is to correlate the geometry and orientation of conductors in the MT model with the postulated spatial extent of other geophysical and geological records across the survey region. In addition, the resistivities within the 3D model of the lithosphere shed light on the degree of fertilisation and depletion of the crust and mantle and constrain the association to a unique or limited number of tectonic events. We discuss these in terms of three main features of the lithosphere: the $\mathrm{N}-\mathrm{S}$-orientated 

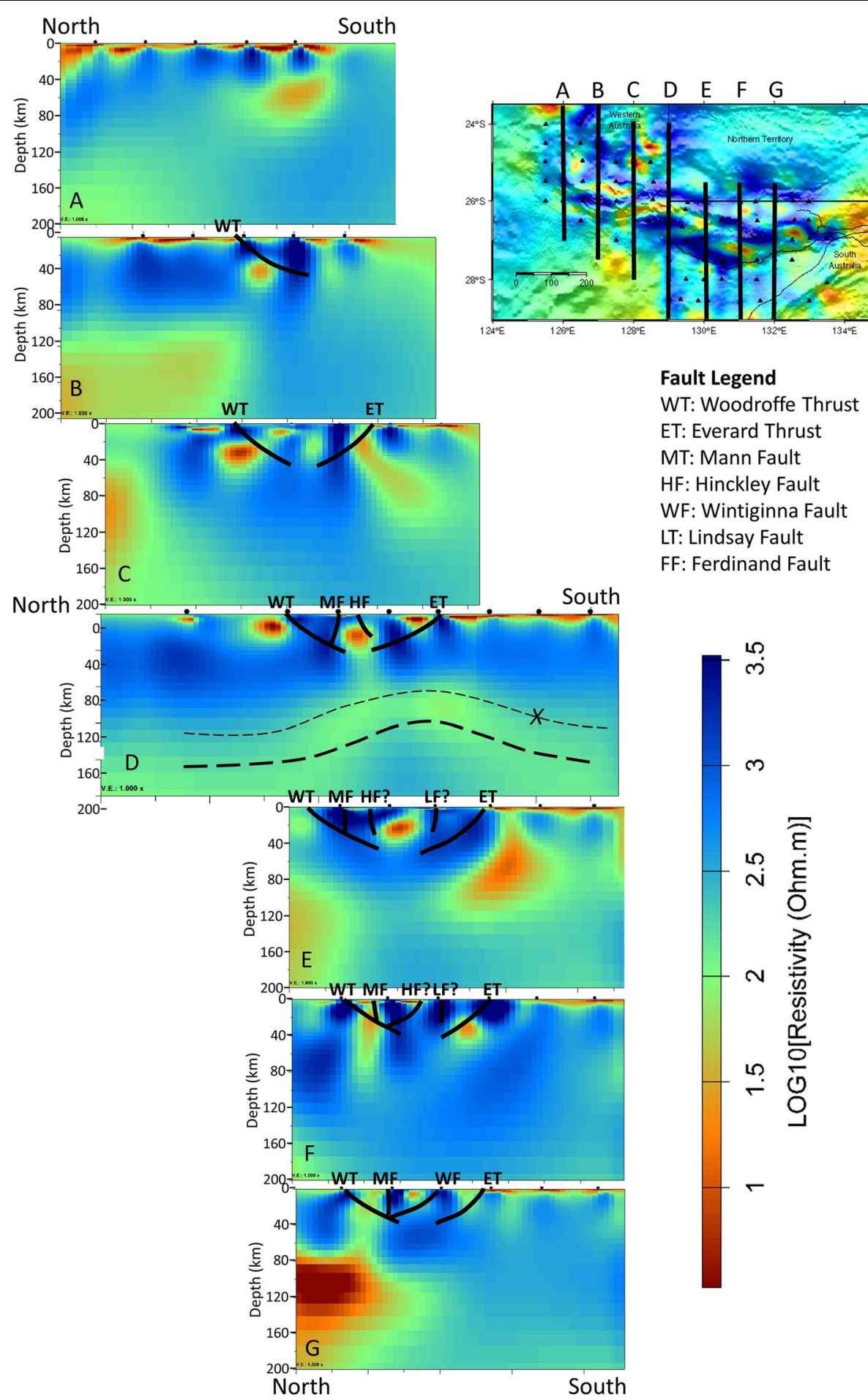

Fig. 9 Composite of seven north-south cross-sections through the preferred 3D inverse model of the Musgrave Province. The inferred position of a number of the Musgrave Province's main faults, imaged by the MT survey, is identified and labelled. In particular, the Woodroffe Thrust and the Mann Fault are shown as well as the inferred position of the Mundrabilla Shear Zone (Aitken et al. 2016). The surface ' $X$ ' is interpreted to suggest offsets in the upper mantle. The Western Australia, Northern Territory and South Australia state boundaries are plotted on the inset map for location reference 
mantle features; the resistive mantle; and the E-W-orientated crustal features and shearing.

\section{$\mathrm{N}-\mathrm{S}$ mantle features and arc evolution}

In one of the most fundamental outcomes of this experiment, the mantle lithosphere appears to demonstrate a different resistivity imprint with an almost $90^{\circ}$ switch in orientation compared to the crust and immediate upper mantle ( $\sim 50 \mathrm{~km}$ and shallower). We suggest that this reflects a decoupling of crustal and mantle geodynamics with time, such that the resistivity of the mantle lithosphere records older tectonic processes represented by the c. 1650-1270 Ma volcanic arc-related magmatism. The markedly north-south resistivity trends seen at the western extreme of the model area and throughout the mantle lithosphere beneath the entire survey area likely reflect a north-south-trending grain related to the c. 1650-1270 Ma volcanic arcs (Dutch et al. 2016; Smithies et al. 2015a; Smits et al. 2014). In the mantle at depths greater than $65 \mathrm{~km}$, the $\mathrm{N}-\mathrm{S}$-trending conductors have a width of between 100 and $200 \mathrm{~km}$ (Fig. 7). Given its geometry, it is possible the NNE-trending intercalated conductive and resistive structure is a possible representation of a retreating/migrating, or amalgamating arc environment between c. 1650 and $1270 \mathrm{Ma}$. Within this scenario, melting of the fluid-rich sedimentary layers atop the subducting slab in the mantle fertilises the overlying lithosphere (Wannamaker et al. 2009). As the slab migrated to the west during the Mesoproterozoic, a second fertilised zone would develop at the position of the new arc. In this scenario, the western $\mathrm{N}-\mathrm{S}$-directed mantle conductors would arguably be younger than the ones in the east and reflect the successively younger geological record to the west exemplified in the Palaeo- to Mesoproterozoic arc rocks (Dutch et al. 2016; Howard et al. 2015; Smits et al. 2014; Wade et al. 2006).

\section{Resistive mantle and the Giles Event-Mundrabilla Shear Zone connection}

Furthermore, our model images resistive mantle lithosphere beneath the postulated intersection of the northsouth Mundrabilla Shear Zone with the east-west trend of the Musgrave Province. This zone has been linked to voluminous mafic and ultramafic magmatism of the 1090-1040 Ma Giles Event (Smithies et al. 2015d). Such a mafic event requires mantle melting and hence depletion, imaged as the resistive mantle. The Mundrabilla Shear Zone is a significant structure that can be traced south into Antarctica and is interpreted to have triggered Giles Event magmatism (Aitken et al. 2016; Smithies et al. 2015d). However, the Mundrabilla Shear Zone is not a prominent feature in the 3D resistivity model and does not form a long and linear conductive structure in the crust, as one might expect from its response in the regional magnetics further south in the Coompana Province. Other regional MT datasets in the region support similar conclusions. The 2D east-west MT profile that runs from the edge of the Yilgarn Craton, eastwards across the Albany-Fraser Orogen, (MT profile-12GAAF3) (Spratt et al. 2014), the Madura and Coompana Provinces, eastwards to the northern part of the Fowler Domain and western margin of the Gawler Craton (MT profile-13GA-EG1) also does not show a vertical conductivity response at the location of the Mundrabilla Shear Zone (Thiel et al. 2016a; Wise and Thiel 2020), yet it is clearly visible in the seismic reflection profile and the regional magnetics.

Rather, the position of the Mundrabilla Shear Zone is inferred by offset of the east-west-trending crustal conductors on either side of the inferred position of the Mundrabilla Shear Zone imaged in the 3D AusLAMP model (Fig. 7). The preferred electrical current flow and associated geoelectric strike in the lower crust and upper mantle follow the main subregions of the Gawler Craton, i.e. a north-northeast direction in the Gawler Craton and changing to due north direction for the Nullarbor Region (Thiel et al. 2016a; Wise and Thiel 2020) aligning with the orientation of the Mundrabilla Shear Zone in the south. Based on our results, the inferred position of the Mundrabilla Shear Zone is depicted in Fig. 7c based on lateral offset of the E-W-trending crustal conductivity zones. It has been postulated that the transpressional movement along the Mundrabilla Shear Zone leads to the widespread triggering of voluminous emplacement of mafic and ultramafic material into the crust at c. $1074 \mathrm{Ma}$ (Smithies et al. 2015a), leaving behind a depleted mantle. Our model is consistent with this interpretation and we image an $\mathrm{N}-\mathrm{S}$-trending resistive mantle lithosphere in the western half of the survey area roughly parallel to the Mundrabilla Shear Zone in the crust and also underlying the Nebo Babel $\mathrm{Ni}-\mathrm{Cu}$ deposit. Intrusions of the Giles Event can be traced south of the survey area into the Coompana Province as a series of circular remanently magnetised bodies (Fig. 2) (Pawley et al. 2018). We should note that the north-northeast-trending mantle resistor in the western part of the survey area may be either the result of the c. 1650-1270 Ma arc system, or it could be related to upper mantle depletion during Giles Event magmatism at c. 1090-1040 Ma, as explained above, or both. We cannot distinguish the cause from the resistivity model alone, yet both could plausibly lead to the resistive mantle lithosphere.

\section{E-W crustal features and shearing}

Results also show a number of significant east-westtrending conductors in the preferred MT model that are 
restricted to the crust (Fig. 7). There is a strong similarity between these conductors and the dominant structural grain mapped throughout the crust of the Musgrave Province, both in aerial extent and at depth (Figs. 2, 3). At the surface, the dominant east-west shear zones, e.g. Mann, Hinckley, Wintiginna faults and the Woodroffe and Everard thrusts (Fig. 2) subdivide the Musgrave Province into a number of east-west-trending zones, consistent with the east-west-trending crustal zonation of resistivity in the MT data (Fig. 7).

The main E-W crustal conductor through the central part of the Musgraves and our survey area spatially coincides with a co-linear gravity high (Fig. 7). The gravity anomalies have been associated with mantle uplift during the Petermann Orogeny (Aitken et al. 2009; Korsch and Kositcin 2010; Lambeck and Burgess 1992), emplacing higher density material at lower crustal levels leading to lithospheric strengthening. We observe a conductivity anomaly associated with the geometry implied from petrologically constrained gravity forward modelling (Aitken et al. 2009), which further supports that at least some of the wide-spread linear E-W-trending crustal conductors are caused by intraplate processes, such as the Petermann and Alice Springs orogenies (Edgoose et al. 2004; Flöttmann et al. 2004; Hand and Sandiford 1999; Lindsay and Leven 1996; Sandiford and Hand 1998).

There is also first-order similarity between the preferred model with steeply dipping resistivity structures and results obtained from passive seismic, teleseismic and deep seismic reflection studies (Fig. 9) (Goleby et al. 1988; Korsch and Kositcin 2010; Neumann 2013). The GOMA seismic reflection line (08GA-OM1) to the east shows that the east-west-trending structures in the Musgrave Province change from north dipping in the southern part of the province (e.g. the Everard Thrust along the southern margin of the province), to south dipping in the north (Fig. 9); e.g. the Woodroffe Thrust (Korsch and Kositcin 2010). To the west, the north-eastern portion of the YOM seismic reflection line (13GA-YO1) shows the prominent south-dipping structures in the northern Musgrave Province, including the dip-slip Woodroffe Thrust and dextral strike-slip Mitika Fault (Howard et al. 2015).

The YOM MT Survey crossing the south-western part of the Musgrave Province, Duan et al. (2013) suggest a model with a lower resistivity region in the middle and lower crust beneath the southern Musgrave Province. Duan et al. (2013) also identified a southwest-dipping boundary in the resistivity model that approximates with the location of the Woodroffe Thrust in that area (Fig. 10). The Musgrave Province region immediately further south-west of this thrust appears to be characterised by very high resistivity values of about $10000 \Omega \mathrm{m}$ in the upper crust. We image a similar southwest-dipping feature in the 3D dataset presented herein (see north-south profiles, Fig. 9).

We also propose that the electrical resistivity variations imaged are related to geodynamically created porosity pathways within the rock fabric created during emplacement and/or deformation. These rheologically weak zones provide pathways for fluids or magmas in the right temperature/pressure regime that can result in enhanced and pervasive electrical conductivity. Once far-field stresses subside, remnants of the dynamically created porosity likely leave an imprint in the rocks long after the fabric is sealed, as mineral precipitates and alterations within the pathways or zones can still be imprinted and are a low-resistivity product of past deformation (Yang et al. 2015; Thiel et al. 2016b). From modern day examples of collision zones, Yang et al. (2015) propose higher conductivities can be the result of conductive minerals (e.g. sulphide or carbon) being subducted to great depths, or resulting from mineral shearing during subduction. This is consistent with the structures imaged across the Musgrave Province.

We infer that the more conductive features represent large-scale overprints in an otherwise resistive lithosphere. The abundance of A-type granites in the Musgrave Province may hint at similar conduction mechanisms for the conductors observed for enhanced conductivity structures in the Gawler Craton (Heinson et al. 2018; Skirrow et al. 2018) and the Coompana Province (Wise and Thiel 2020). These could be a higher Fe-content in the form of magnetite or possibly fluorine enrichment (Xing et al. 2019; Li et al. 2016; Skirrow et al. 2018; Thiel and Heinson 2013). These electrical resistivity variations are likely related to past enhanced porosity created during emplacement and/or deformation acting as conduits to fluid/magma flux through the lithosphere. Even after closure of the permeable pathways to fluids, mineral precipitates may survive over much longer periods of time giving rise to enhanced conductivity structures seen today.

Finally, the 3D MT data of this survey are companion to that collected as part of the SA AusLAMP MT survey collected MT data for the Officer and Gawler Craton and eastwards under the Cooper basin. Thiel et al. (2018), in interpreting the SA AusLAMP dataset, particularly over the Gawler Craton to the south, conclude the Gawler Craton MT signature suggests ponding of fluids beneath the brittle-ductile transition zone in the ductile regime of the crust. Heinson et al. (2018) suggest that fluids moved into the upper brittle crust forming narrow pathways to the surface, which are imaged as steep changes in resistivity. Thiel et al. (2018) note the thickest zone of resistive core correlates with lithosphere-asthenosphere 


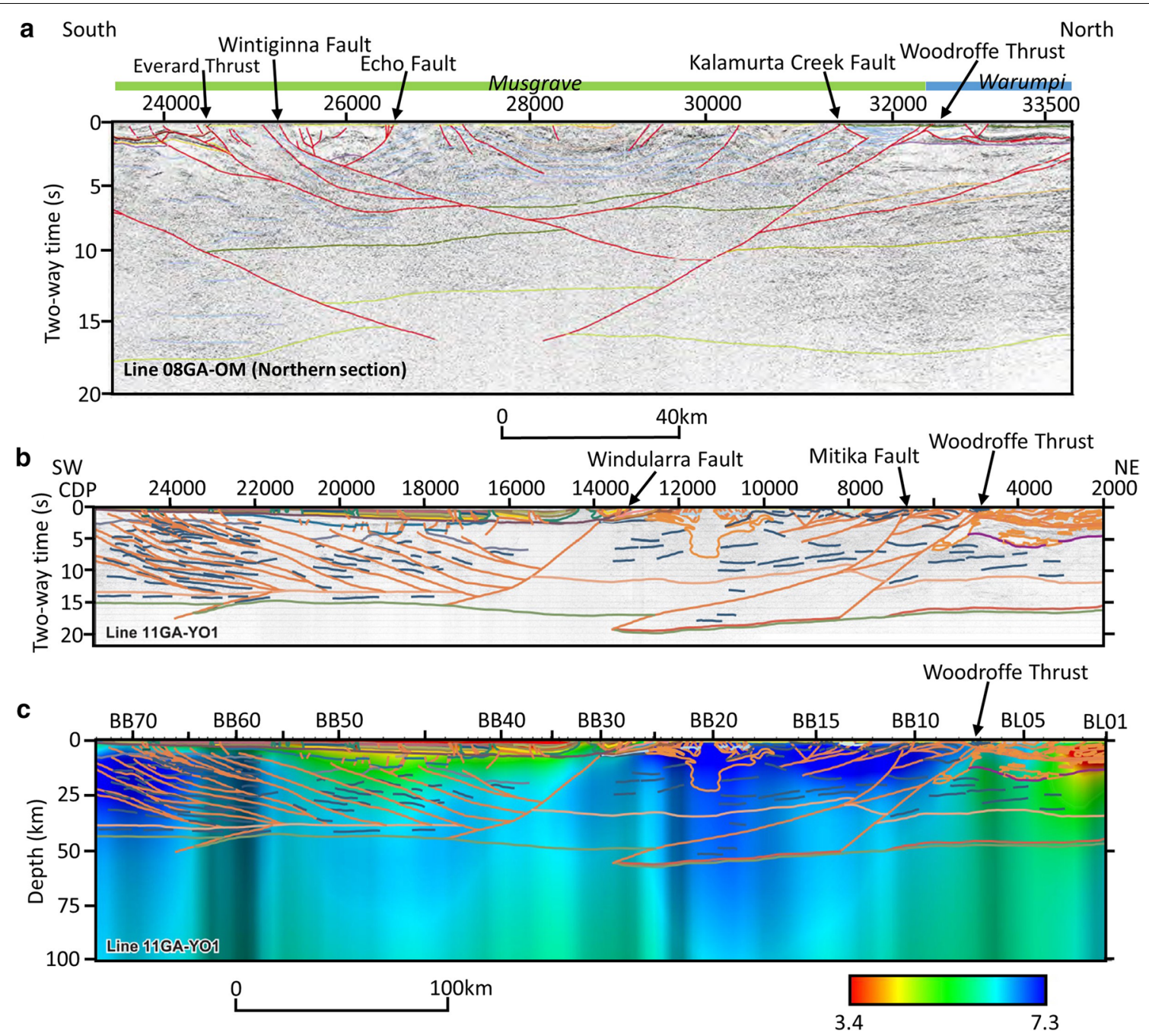

Fig. 10 Deep seismic reflection sections imaging the Musgrave Province. a Interpreted migrated seismic reflection section for the northern portion of the GOMA Seismic Survey (08GA-OM1). Provinces and key faults are named. The display is $\sim 60 \mathrm{~km}$ depth, with V/H $\sim 1$, assuming an average crustal velocity of $6000 \mathrm{~m} \cdot \mathrm{s}^{-1}$. The location of this seismic traverse is shown in Figs. 1 and 2 (Korsch and Kositcin 2010). $\mathbf{b}$ Interpreted migrated seismic reflection section for the north-eastern portion of the YOM Seismic Survey (11GA-YO1). Key faults are named. The display is $\sim 60 \mathrm{~km}$ depth, with $\mathrm{V} / \mathrm{H} \sim 1$, assuming an average crustal velocity of $6000 \mathrm{~m} \cdot \mathrm{s}^{-1}$. The location of this seismic traverse is shown in Figs. 1 and 2 (Korsch et al. 2013). c Seismic interpretation from 10B above plotted on 2D MT model acquired along the north-eastern portion of the YOM Seismic Survey (11GA-YO1) (Korsch et al. 2013). All three images are reprinted with permission from Geoscience Australia under copyright Commonwealth of Australia (Geoscience Australia) 2019. This Fig. is released under the Creative Commons Attribution 4.0 International Licence. http://creativecommons.org/ licenses/by/4.0/legalcode

boundary estimates derived from seismic tomography studies and thermal models of the lithosphere (Kennett and Iaffaldano 2013). Thiel et al. (2018) conclude that large-scale vertical low-resistivity zones often demarcate long-lived terrane boundaries, and that mantle conductors signify past lithosphere fertilisation events (Thiel and Heinson 2013). We also see this correlation in the Musgrave Province data in the eastern-most part (Fig. 9g where the Musgrave Province abuts the Gawler Craton.

\section{Conclusion}

The new 3D MT data collected across the Musgrave Province, Central Australia provide new insights into the geological history of the Musgrave region. The 3D MT model presented images of the province's 3D internal crustal structure, as well as structure within the mantle. The improved understanding gained through $3 \mathrm{D}$ acquisition also assisted in understanding of known deformation events. 
The 3D MT model defines two predominant resistivity trends: a deeper lithospheric $(>65 \mathrm{~km})$ northsouth-trending conductivity structure that is inferred to represent original whole-of-lithosphere deformation structures formed during docking of the North Australian Craton and proto-South Australian Cratons to the existing older West Australian and the formation of the proto-Musgrave Province, and a stronger and more pervasive east-west conductivity structure in the crust representing more recent deformations during the Musgrave Orogeny (c.1220-1150 Ma), the Petermann Orogeny (c.630-520 Ma) and the Alice Springs Orogeny (c.380 $\mathrm{Ma}$ ). These east-west electrical structures correlate with regional gravity highs as well as inferred Moho offsets from gravity forward modelling (Aitken et al. 2009).

At the regional scale, the MT data have imaged internal structure within the Musgrave Province, identifying a number of significant crustal-scale east-west-orientated conductors that are north-dipping to the north of the Woodroffe Thrust then become predominantly southdipping from the Woodroffe Thrust southwards throughout the central part of the Musgrave Province to the southern margin of the Musgrave Province. South of the Musgrave Province, there appears to be evidence of further minor northward-dipping structures.

The 3D MT Model presented shows evidence of an arcuate south-west boundary to the Musgrave Province, with east to northeast-dipping structures at the western margin of the Musgrave Province.

\begin{abstract}
Abbreviations
ANSIR: Research Facilities for Earth Sounding (http://ansir.org.au/), originally the Australian National Seismic Imaging Resources; APY: Anangu Pitjantjatjara Yankunytjatjara (APY) Lands of South Australia; AusLAMP: Australian Lithospheric Architecture Magnetotelluric Project; EDI: Electrical Data Interchange format; ModEM: Modular Electromagnetic MT Modelling code by Egbert and Kelbert (2012), Kelbert et al. (2014); MT: Magnetotellurics; NCl: National Computing Infrastructure, Australia (https://nci.org.au/); RMS: root mean squared.
\end{abstract}

\section{Acknowledgements \\ Ms. Philippa Mawby and Mr. Geoff Axford are thanked for their assistance in collection of the MT data and their help with land access permissions. We thank the Indigenous land owners of the Ngganyatjarraku Lands and Anangu Pitjantjatjarra Yankunytjatjara Lands for access onto both their countries and for assistance in finding suitable MT sites and assisting in the deployment of the MT equipment. Data collection was funded primarily by AuScope Ltd, with additional support from the Geological Survey of South Australia. Data was collected using the ANSIR (Research Facility for Earth Sounding)/AuScope National MT instrument pool. Data plots created using 3D Grid (developed by Naser Meqbel) and GMT (Wessel et al. 2013). Inversions were run on the $\mathrm{NCl}$ supercomputer, Canberra. The authors thank the reviewers, including Dave Kelsey, and the editor, Kate Selway, for helpful comments on the original manuscript.}

\section{Authors' contributions}

Each author contributed to the preparation and reviewing of the manuscript and interpretation of the MT data. BG conducted the initial data processing from time series to frequency domain. ST produced the 3D Inversion models for the survey area and undertook robustness tests. BG and ST created figures for the manuscript. MP provided the geological background information and contributed to the interpretation. All authors read and approved the final manuscript.

\section{Funding}

MT data collection was funded primarily by AuScope Ltd, with assistance from the Geological Survey of South Australia. Time series to final electrical response result (EDI) processing was jointly funded by OPM Consulting Pty Ltd and AuScope Ltd. 3D Modelling and inversion was funded by the Geological Survey of South Australia.

\section{Availability of data and materials}

All MT data collected have been archived through the SARIG portal of the Geological Survey of South Australia (https://map.sarig.sa.gov.au/), University of Adelaide, School of Physical Science, and at the National Computing Infrastructure (NCl) Australia. The $\mathrm{NCl}$ is working to have all these data discoverable and publically downloadable in netCDF format.

\section{Ethics approval and consent to participate}

This manuscript does not report studies involving human participants, human data or human tissue oy any kind. Ethics approval and consent is not applicable.

\section{Consent for publication}

This manuscript does not contain any individual person's data in any form. Hence, the consent for publication statement is not applicable.

\section{Competing interests}

None of the authors have any financial or non-financial competing interests in this paper.

\section{Author details}

${ }^{1}$ Department for Energy and Mining, Geological Survey of South Australia, Adelaide, SA 5000, Australia. ${ }^{2}$ OPM Consulting Pty Ltd, Gowrie, ACT 2904, Australia. ${ }^{3}$ School of Physical Sciences, The University of Adelaide, Adelaide, SA 5005, Australia.

\section{Appendix A. The Magnetotelluric method}

The MT method is a passive electromagnetic geophysical technique that records Earth's electrical response to natural, time-varying magnetic fields at the surface of the Earth (Cagniard 1953; Chave and Jones 2012). For lithospheric MT investigations, one needs to record timevarying fields between bandwidths of $1 \mathrm{~s}$ and 10,000 s. The source field for this bandwidth is caused by interactions between solar winds and Earth's ionosphere and magnetosphere (Cagniard 1953; Chave and Jones 2012).

In practice, MT recording system sample time series of orthogonal horizontal electric fields (E field as $E_{x}$ and $E_{y}$ ) and three-component magnetic induction (B field as $B_{x}$, $B_{y}$ and $B_{z}$ ), where $x, y$ and $z$ refer to geographic north, east, and vertically down directions. The time series is converted into the frequency domain using Fourier robust remote-referencing processing schemes (Chave and Thomson 2004; Chave 2014). The period $T$ of the recorded signal as well as the bulk resistivity of the subsurface $\rho_{a}$ determines the penetration depth $\delta$ (in $\Omega \mathrm{m}$ ) of the signal via the skin-depth formula, noting that skin depth relies heavily on a half-space assumption and is only a rough approximation in a 3D setting:

$$
\delta(T) \approx 500 \sqrt{T \cdot \rho_{a}} .
$$


Although the resistivity of rocks can vary by more than 14 orders of magnitude (Nover 2005), a reasonable average crustal resistivity of $100 \Omega \mathrm{m}$ implies a skin depth of about $500 \mathrm{~km}$ for signal of periodicity $10^{4} \mathrm{~s}$ (frequency of $0.0001 \mathrm{~Hz}$ ). At the shortest period of $1 \mathrm{~s}$, the skin depth is approximately $1 \mathrm{~km}$ to $2 \mathrm{~km}$ for a typical sediment cover resistivity of $1 \Omega \mathrm{m}-10 \Omega \mathrm{m}$, placing a limit in terms of resolution in the upper crust.

The ratio of the horizontal electric to magnetic induction, as a function of period $\mathrm{T}$, yields the impedance tensor $\mathrm{Z}$ from

$$
\left[\begin{array}{ll}
E_{x} & E_{y}
\end{array}\right]=\left[\begin{array}{ll}
Z_{x x} & Z_{x y} \\
Z_{y x} & Z_{y y}
\end{array}\right]\left[\begin{array}{l}
B_{x} \\
B_{y}
\end{array}\right] .
$$

The impedance tensor $\mathrm{Z}$ is a complex, frequency-dependent tensor that contains all the information about subsurface resistivity and can be used to calculate the apparent resistivity and impedance phase (Cagniard 1953). The impedance phase relates the phase difference between the inducing magnetic field and the induced electric field. Each component of $Z=X+i Y$ can be expressed as a magnitude $\rho_{a}$ and phase $\varphi$ (Chave and Jones 2012), as follows:

$$
\rho_{a}=\frac{1}{\omega \mu_{0}}\left\|Z_{i j}\right\|^{2}
$$

where $\omega$ is the angular frequency, and $\mu_{0}$ is the magnetic permeability, and

$$
\varphi=\tan ^{-1} \frac{\mathfrak{I} Z_{i j}}{\mathfrak{R} Z_{i j}}
$$

where $\mathfrak{I}$ and $\mathfrak{R}$ denote the imaginary and real parts of $Z_{i j}$.

An alternative way to represent the impedance tensor information is the galvanic distortion-free MT phase tensor. This is important in MT processing as this tensor is unaffected by distortions caused by near-surface and small-scale inhomogeneities and therefore can be used to estimate and remove distortion from $\mathrm{Z}$ (Caldwell et al. 2004; Bibby et al. 2005; Booker 2014). The galvanic distortion-free MT phase tensor is expressed as

$$
\Phi=X^{-1} Y .
$$

This can be displayed as an ellipse and shows the dimensionality and strike of the impedance tensor. Onedimensional resistivity distributions are characterised by a circle whereas $2 \mathrm{D}$ or $3 \mathrm{D}$ resistivity distributions are ellipses, with a non-zero value of the phase tensor skew indicating 3D induction. The principal components of the phase tensor denote the transverse electric and transverse magnetic polarisation phases and in $3 \mathrm{D}$ and the ellipses will be elongated in a skewed direction of current flow (Booker 2014).

Induced electrical currents flowing along strong elongated subsurface conductors, where current flows in a preferred geoelectric strike direction, create anomalous vertical magnetic fields. The measured vertical magnetic field $\left(B_{z}\right)$ is related to the measured horizontal magnetic fields $\left(B_{x}, B_{y}\right)$ through a frequency-dependent complex magnetic transfer function. Graphically, this complex magnetic transfer function is represented by an induction arrow whose in-phase or real components points towards good conductors and imaginary part provides information about the dimensionality of the conductive anomaly (Parkinson 1962). Arrow length represents the strength of vertical magnetic fields and is useful for locating lateral boundaries of subsurface conductors (Parkinson 1962).

Controls on conductivity and what can be imaged by the MT method have been well covered elsewhere (Glover 1996; Bedrosian 2007; Selway 2014; Thiel 2017); however, in essence the electrical response of rocks is usually affected by the connectedness of fluids, e.g. brines, pore water and by the presence of metallic or semiconductor minerals, e.g. sulphides, graphite. Fluids require a connected porosity to cause a significant reduction in electrical resistivity, with sedimentary basins a prime example. Recent laboratory studies indicate that even mid-crustal shear zones can have sufficient porosity to sustain an enhanced conductivity response over time, either through fluids or their precipitates (Fusseis et al. 2009).

Received: 8 July 2019 Accepted: 27 June 2020

Published online: 11 July 2020

$$
\begin{aligned}
& \text { References } \\
& \text { Aitken A, Betts P, Young D, Blankenship D, Roberts J, Siegert M (2016) The } \\
& \text { Australo-Antarctic Columbia to Gondwana transition. Gondwana Res } \\
& \text { 29:136-152. https://doi.org/10.1016/j.gr.2014.10.019 } \\
& \text { Aitken A, Dentith M, Evans S, Gallardo L, Joly A, Thiel S, Smithies R, Tyler I } \\
& \text { (2013) Imaging crustal structure in the west Musgrave Province from } \\
& \text { magnetotelluric and potential field data. Technical Report Report } 114 . \\
& \text { Geological Survey of Western Australia } \\
& \text { Aitken ARA, Betts PG (2008) High-resolution aeromagnetic data over central } \\
& \text { Australia assist Grenville-era (1300-1100 ma) Rodinia reconstructions. } \\
& \text { Geophys Res Lett. https://doi.org/10.1029/2007gl031563 } \\
& \text { Aitken ARA, Betts PG, Weinberg RF, Gray D (2009) Constrained potential field } \\
& \text { modeling of the crustal architecture of the musgrave province in } \\
& \text { central Australia: evidence for lithospheric strengthening due to crust- } \\
& \text { mantle boundary uplift. J Geophys Res. https://doi.org/10.1029/2008J } \\
& \text { B006194 } \\
& \text { Alghamdi AH, Aitken AR, Dentith MC (2018) The deep crustal structure of the } \\
& \text { warakurna lip, and insights on proterozoic lip processes and mineralisa- } \\
& \text { tion. Gondwana Res 56:1-11 } \\
& \text { Bedrosian P (2007) MT+, integrating magnetotellurics to determine earth } \\
& \text { structure, physical state, and processes. Surv Geophys 28:121-167 } \\
& \text { Betts PG, Giles D (2006) The 1800-1100 Ma tectonic evolution of Australia. } \\
& \text { Precambrian Res 144:92-125 }
\end{aligned}
$$


Bibby HM, Caldwell TG, Brown C (2005) Determinable and non-determinable parameters of galvanic distortion in magnetotellurics. Geophys J Int 163:915-930. https://doi.org/10.1111/j.1365-246X.2005.02779.x

Booker J (2014) The Magnetotelluric Phase Tensor: A Critical Review. Surveys in Geophysics 35:7-40

Cagniard L (1953) Basic theory of the magneto-telluric method of geophysical prospecting. Geophysics 18:605-635

Caldwell TG, Bibby HM, Brown C (2004) The magnetotelluric phase tensor. Geophys J Int 158:457-469. https://doi.org/10.1111/j.1365246X.2004.02281.X/pdf

Camacho A, Fanning C (1995) Some isotopic constraints on the evolution of the granulite and upper amphibolite facies terranes in the eastern Musgrave Block, central Australia. Precambrian Res 71:155-181. https:// doi.org/10.1016/0301-9268(94)00060-5

Camacho A, McDougall I (2000) Intracratonic, strike-slip partitioned transpression and the formation and exhumation of eclogite facies rocks: An example from the musgrave block, central australia. Tectonics 19:978-996. https://doi.org/10.1029/1999tc001151

Camacho A, Simons B, Schmidt PW (1991) Geological and palaeomagnetic significance of the kulgera dyke swarm, musgrave block, NT, australia. Geophys J Int 107:37-45. https://doi.org/10.1111/j.1365-246x.1991. tb01154.x

Chave AD (2014) Magnetotelluric data, stable distributions and impropriety: an existential combination. Geophys J Int 198:622-636. https://doi. org/10.1093/gji/ggu121

Chave AD, Jones AG (2012) The magnetotelluric method: theory and practice. Cambridge University Press, Cambridge

Chave AD, Thomson DJ (2004) Bounded influence magnetotelluric response function estimation. Geophys J Int 157:988-1006

Clark D, Hensen B, Kinny P (2000) Geochronological constraints for a two-stage history of the Albany-Fraser Orogen, Western Australia. Precambrian Res 102:155-183. https://doi.org/10.1016/s0301-9268(00)00063-2

Clitheroe G, Gudmundsson O, Kennett BLN (2000) The crustal thickness of Australia. J Geophys Res 105:13697-13713. https://doi.org/10.1029/1999j b900317

Collins W, Shaw R (1995) Geochronological constraints on orogenic events in the Arunta Inlier: a review. Precambrian Res 71:315-346. https://doi. org/10.1016/0301-9268(94)00067-2

de Gromard RQ, Kirkland CL, Howard HM, Wingate MT, Jourdan F, McInnes BI, Danišik M, Evans NJ, McDonald BJ, Smithies RH (2019) When will it end? long-lived intracontinental reactivation in central australia. Geosci Front 10:149-164. https://doi.org/10.1016/.gsf.2018.09.003

Drexel J, Preiss W, Parker A (1993) Geological framework, vol 1. Geological Survey of South Australia, The Precambrian

Duan J, Milligan P, Fomin T (2013) Electrical resistivity distribution from magnetotelluric data in the Yilgarn Craton, western Officer Basin and western Musgrave Province. In: Neumann N (ed) Yilgarn Craton-Officer Basin-Musgrave Province Seismic and MT Workshop, vol 28. Geoscience Australia, Canberra

Duan J, Milligan P, Nakamura A (2010) Magnetotelluric survey along the GOMA deep seismic reflection transect in the northern Gawler Craton to Musgrave Province, South Australia. In: Korsch R, Kositcin N (eds), GOMA (Gawler Craton-Officer Basin-Musgrave Province-Amadeus Basin) Seismic and MT Workshop 2010, volume 2010/039. Geoscience Australia, Record, pp 7-15

Dutch R (2018) Coompana province geochemistry and petrogenesis. In: Dutch R, Wise T, Pawley M, Petts A (eds) Coompana Drilling and Geochemistry Workshop 2018 extended abstracts. Department for Energy and Mining, South Australia, pp 76-101

Dutch R, Reid A, Smithies R, Payne J, Jagodzinski E, Kirkland C, Pawley M, Spaggiari C, Preiss W (2016) Is Southern Australia bent?; recognition of a contiguous Palaeoproterozoic magmatic arc along the western margin of the Mawson Continent. In: Australian Earth Science Convention: Uncover Earth's Past to Discover Our Future, Adelaide, SA, Australia, p. 120

Edgoose C, Scrimgeour I, Close D (2004) Geology of the Musgrave Block, Northern Territory. Technical Report NTGS Report 15. Northern Territory Geological Survey

Egbert GD, Kelbert A (2012) Computational recipes for electromagnetic inverse problems. Geophys J Int 189:251-267
Evins P, Kirkland C, Wingate M, Smithies R, Howard H, Bodorkos S (2012) Provenance of the 1340-1270 Ma Ramarama Basin in the west Musgrave Province, Central Australia. Technical Report 116. Geological Survey of Western Australia

Evins PM, Smithies RH, Howard HM, Kirkland CL, Wingate MT, Bodorkos S (2010) Devil in the detail: the 1150-1000 Ma magmatic and structural evolution of the Ngaanyatjarra Rift, west Musgrave Province, Central Australia. Precambrian Res 183:572-588. https://doi.org/10.1016/j.preca mres.2010.02.011

Fichtner A, Kennett BL, Igel H, Bunge HP (2010) Full waveform tomography for radially anisotropic structure: new insights into present and past states of the australasian upper mantle. Earth Planet Sci Lett 290: 270-280. http://www.sciencedirect.com/science/article/B6V61-4Y5H6 4W-1/2/760f125e98261617ed23a1273d526be8

Fishwick S, Reading A (2008) Anomalous lithosphere beneath the Proterozoic of western and central Australia: A record of continental collision and intraplate deformation?. Precambrian Research 166:111-121. http:// www.sciencedirect.com/science/article/B6VBP-4SH6BD6-1/2/7e191 536ae4daa56311d5304807b7f7a

Flöttmann T, Hand M, Close D, Edgoose C, Scrimgeour I (2004) Thrust tectonic styles of the intracratonic alice springs and petermann orogenies, central australia. In: Thrust Tectonics and Hydrocarbon Systems. American Association of Petroleum Geologists, pp 551-570. https://doi. org/10.1306/m82813c28

Fusseis F, Regenauer-Lieb K, Liu J, Hough RM, De Carlo F (2009) Creep cavitation can establish a dynamic granular fluid pump in ductile shear zones. Nature 459:974-977

Gaul OF, O'Reilly SY, Griffin WL (2003) Lithosphere structure and evolution in southeastern australia. Geological Society of America Special Papers 372:185-202. http://specialpapers.gsapubs.org/content/372/185.abstr act, https://doi.org/10.1130/0-8137-2372-8.185

Giles D, Betts PG, Lister GS (2004) 1.8-1.5-Ga links between the north and south Australian cratons and the early-middle proterozoic configuration of Australia. Tectonophysics 380:27-41

Glikson A, Stewart A, Ballhaus C, Clarke G, Feeken E, Leven J, Sheraton J, Sun S (1996) Geology of the western Musgrave Block, central Australia, with particular reference to the mafic-ultramafic Giles Complex. resreport. Australian Geological Survey Organisation. Canberra, Australia

Glorie S, Agostino K, Dutch R, Pawley M, Hall J, Danišík M, Evans NJ, Collins AS (2017) Thermal history and differential exhumation across the eastern musgrave province, south australia: Insights from low-temperature thermochronology. Tectonophysics 703-704:23-41. https://doi. org/10.1016/j.tecto.2017.03.003

Glover PWJ (1996) Graphite and electrical conductivity in the lower continental crust: a review. Phys Chem Earth 21:279-287

Goleby BR, Shaw RD, Wright C, Kennett BL, Lambeck K (1989) Geophysical evidence for'thick-skinned' crustal deformation in central australia. Nature 337:325-330

Goleby BR, Wright C, Collins CDN, Kennett BLN (1988) Seismic reflection and refraction profiling across the Arunta Block and the Ngalia and Amadeus Basins. Aust J Earth Sci 35:275-294. https://doi.org/10.1080/08120 098808729447

Gorczyk W, Vogt K (2015) Tectonics and melting in intra-continental settings. Gondwana Res 27:196-208. https://doi.org/10.1016/j.gr.2013.09.021

Gravestock D, Benbow M, Gatehouse C, Krieg G (1995) Eastern officer basin. In: Drexel J, Preiss W (eds) The Geology of South Australia, vol 2. The Phanerozoic, Geological Survey of South Australia, pp 35-41

Griffin WL, Begg GC, O'Reilly SY (2013) Continental-root control on the genesis of magmatic ore deposits. Nat Geosci 6:905-910

Hand M, Sandiford M (1999) Intraplate deformation in central Australia, the link between subsidence and fault reactivation. Tectonophysics 305:121-140

Heinson G, Didana Y, Soeffky P, Thiel S, Wise T (2018) The crustal geophysical signature of a world-class magmatic mineral system. Sci Rep 8:10608. https://doi.org/10.1038/s41598-018-29016-2

Heise W, Caldwell T, Bibby H, Brown C (2006) Anisotropy and phase splits in magnetotellurics. Phys Earth Planet Interiors 158:107-121

Howard H, Smithies R, Kirkland C, Kelsey D, Aitken A, Wingate M, de Gromard RQ, Spaggiari C, Maier W (2015) The burning heart-the proterozoic geology and geological evolution of the west musgrave region, central australia. Gondwana Res 27:64-94 
Howard KE, Hand M, Barovich KM, Payne JL, Belousova EA (2011) U-Pb, Lu-Hf and $\mathrm{Sm}-\mathrm{Nd}$ isotopic constraints on provenance and depositional timing of metasedimentary rocks in the western Gawler Craton: Implications for Proterozoic reconstruction models. Precambrian Res 184:43-62

Hyndman RD, Shearer PM (1989) Water in the lower continental crust: modelling magnetotelluric and seismic reflection results. Geophys J Int 98:343-365

Jagodzinski E, Bodorkos S, Crowley J, Pawley M, Wise T (2018) PACE Copper Coompana Drilling Project: U-Pb dating of basement and cover rocks. Technical Report, Department for Energy and Mining, South Australia, Adelaide

Jagodzinski E, Dutch R (2013) SHRIMP U-Pb Geochronology of the Tieyon (5645) 1:100 000 mapsheet. Technical Report, Department for Manufacturing, Innovation, Trade, Resources and Energy, Adelaide, South Australia

Jones A, Ledo J, Ferguson I (2005) Electromagnetic images of the Trans-Hudson orogen: the North American Central Plains anomaly revealed. Can J Earth Sci 42:457-478

Kelbert A, Meqbel N, Egbert GD, Tandon K (2014) Modem: a modular system for inversion of electromagnetic geophysical data. Comput Geosci 66:40-53

Kennett B, laffaldano G (2013) Role of lithosphere in intra-continental deformation: Central Australia. Gondwana Res 24:958-968

Kennett BLN, Fichtner A, Fishwick S, Yoshizawa K (2013) Australian seismological reference model (Ausrem): mantle component. Geophys J Int 192:871-887. https://doi.org/10.1093/gji/ggs065

Kirkland C, Smithies R, Spaggiari C, Wingate M, de Gromard RQ, Clark C, Gardiner N, Belousova E (2017) Proterozoic crustal evolution of the eucla basement, australia: Implications for destruction of oceanic crust during emergence of nuna. Lithos 278-281:427-444

Korsch R, Blewett R, Smithies R, Quentin de Gromard R, Howard H, Pawley M, Carr L, Hocking R, Neumann N, Kennett B, Aitken A, Holzschuh J, Duan J, Goodwin J, Jones T, Gessner K, Gorczyk W (2013) Geodynamic implications of the Yilgarn Craton-Officer Basin-Musgrave Province (YOM) deep seismic reflection survey: part of a $\sim 1800 \mathrm{~km}$ transect across Western Australia from the Pinjarra Orogen to the Musgrave Province. In: Neumann N (ed) Yilgarn Craton-Officer Basin-Musgrave Province Seismic and MT Workshop. Geoscience Australia

Korsch R, Goleby B, Leven J, Drummond B (1998) Crustal architecture of central Australia based on deep seismic reflection profiling. Tectonophysics 288:57-69. https://doi.org/10.1016/s0040-1951(97)00283-7

Korsch R, Kositcin N (eds) (2010) South Australian Seismic and MT Workshop 2010, vol 10. Geoscience Australia, Record

Lambeck K, Burgess G (1992) Deep crustal structure of the Musgrave Block, central Australia: results from teleseismic travel-time anomalies. Aust J Earth Sci 39:1-19. https://doi.org/10.1080/08120099208727996

Li Y, Yang X, Yu JH, Cai YF (2016) Unusually high electrical conductivity of phlogopite: the possible role of fluorine and geophysical implications. Contribut Mineral Petrol 171:1-11. https://doi.org/10.1007/s0041 0-016-1252-x

Lindsay JF (2002) Supersequences, superbasins, supercontinents-evidence from the neoproterozoic-early palaeozoic basins of central australia. Basin Resarch 14:207-223. https://doi.org/10.104 6/j.1365-2117.2002.00170.x

Lindsay JF, Leven JH (1996) Evolution of a Neoproterozoic to Palaeozoic intracratonic setting, Officer Basin, South Australia. Basin Res 8:403-424. https ://doi.org/10.1046/j.1365-2117.1996.00223.x

Major R, Conor C (1993) The geology of South Australia. In: Preiss W, Parker A, Drexel I (eds) Musgrave block. Geological Survey of South Australia, Australia, pp 156-167

Mawby J, Hand M, Foden J (1999) Sm-nd evidence for high-grade ordovician metamorphism in the arunta block, central australia. J Metamorphic Geol 17:653-668. https://doi.org/10.1046/j.1525-1314.1999.00224.x

Meqbel NM, Egbert GD, Wannamaker PE, Kelbert A, Schultz A (2014) Deep electrical resistivity structure of the northwestern U.S. derived from 3-D inversion of USArray magnetotelluric data. Earth Planet Sci Lett 402:290-304

Neumann N (2013) Yilgarn Craton-Officer Basin-Musgrave Province Seismic and MT Workshop. Technical Report Record 2013/28. Geoscience Australia
Nover G (2005) Electrical properties of crustal and mantle rocks: a review of laboratory measurements and their explanation. Surv Geophys 26:593-651

O'Reilly S, Griffin W (2010) The continental lithopshere-asthenosphere boundary: can we sample it? Lithos 120:1-13

Parkinson W (1962) The influence of continents and oceans on geomagnetic variations. Geophys J R Astron Soc 6:441-449

Pawley M, Dutch R, Jagodzinski E, Werner M, Hand M (2016) Finding closure: multiple stages of Musgravian-aged deformation in the eastern Musgrave Province. In: 2016 Australian Earth Science Convention: Uncover Earth's Past to Discover Our Future. Adelaide, South Australia

Pawley M, Dutch R, Werner M, Krapf C (2014) Repeated failure: long-lived faults in the eastern musgrave province. MESA Journal

Pawley M, Dutch R, Wise T (2018) The coompana province: structural insights and prospectivity. In: Reid A (ed) Geological Survey of South Australia Discovery Day 2018: Presentation abstracts and posters. Department for Energy and Mining, South Australia, pp 19-24

Pollett A, Thiel S, Bendall B, Raimondo T, Hand M (2019) Mapping the Gawler Craton-Musgrave Province interface using integrated heat flow and magnetotellurics. Tectonophysics 756:43-56. https://doi.org/10.1016/j. tecto.2019.02.017

Pommier A (2014) Interpretation of magnetotelluric results using laboratory measurements. Surv Geophys 35:41-84

Raimondo T, Collins AS, Hand M, Walker-Hallam A, Smithies RH, Evins PM, Howard HM (2010) The anatomy of a deep intracontinental orogen. Tectonics. https://doi.org/10.1029/2009tc002504

Rawlinson N, Salmon M, Kennett B (2014) Transportable seismic array tomography in southeast Australia: illuminating the transition from proterozoic to phanerozoic lithosphere. Lithos 189:65-76

Robertson K, Heinson G, Thiel S (2016) Lithospheric reworking at the Proterozoic-Phanerozoic transition of Australia imaged using AusLAMP Magnetotelluric data. Earth Planet Sci Lett 452:27-35

Robertson K, Thiel S, Meqbel N (2020) Quality over quantity: on workflow and model space exploration of 3D inversion of MT data. Earth Planets Space 72:2. https://doi.org/10.1186/s40623-019-1125-4

Salmon M, Kennett BLN, Saygin E (2013) Australian seismological reference model (ausrem): crustal component. Geophys J Int 192:190-206. arXiv :http://gji.oxfordjournals.org/content/192/1/190.full.pdf+html

Sandiford M, Hand M (1998) Controls on the locus of intraplate deformation in central Australia. Earth Planet Sci Lett 162:97-110

Saygin E, Kennett BL (2010) Ambient seismic noise tomography of australian continent. Tectonophysics 481:116-125 http://www.sciencedirect. com/science/article/B6V72-4V1KMKC-1/2/f8ab0c3cfa2d283dd3af65e4a 0b91a14

Scrimgeour I, Close D (1999) Regional high-pressure metamorphism during intracratonic deformation: the Petermann Orogeny, central Australia. J Metamorphic Geol 17:557-572. https://doi.org/10.104 6/j.1525-1314.1999.00217.x

Selway K (2014) On the causes of electrical conductivity anomalies in tectonically stable lithosphere. Surv Geophys 35:219-257. https://doi. org/10.1007/s10712-013-9235-1

Selway K, Hand M, Payne J, Heinson G, Reid A (2011) Magnetotelluric constraints on the tectonic setting of Grenville-aged orogenesis in central Australia. J Geol Soc 168:251-264

Selway K, Yi J, Karato SI (2014) Water content of the tanzanian lithosphere from magnetotelluric data: Implications for cratonic growth and stability. Earth Planet Sci Lett 388:175-186. https://doi.org/10.1016/j. epsl.2013.11.024

Skirrow RG, van der Wielen SE, Champion DC, Czarnota K, Thiel S (2018) Lithospheric architecture and mantle metasomatism linked to iron oxide cu-au ore formation: Multidisciplinary evidence from the olympic dam region, south australia. Geochemistry, Geophysics, Geosystems. https:// doi.org/10.1029/2018gc007561

Smithies R, Kirkland C, Korhonen F, Aitken A, Howard H, Maier W, Wingate M, de Gromard RQ, Gessner K (2015a) The mesoproterozoic thermal evolution of the musgrave province in central australia-plume vs. the geological record. Gondwana Res 27:1419-1429. https://doi.org/10.1016/j. gr.2013.12.014

Smithies R, Spaggiari C, Kirkland C, Wingate M, England R (2015b) Forrest zone: geochemistry and petrogenesis. In: Spaggiari C, Smithies R (eds), Eucla 
basement stratigraphic drilling results release workshop: extended abstracts. Geological Survey of Western Australia. pp. 17-28

Smithies R, Spaggiari C, Kirkland C, Wingate M, England R (2015c) Madura province: geochemistry and petrogenesis. In: Spaggiari C, Smithies R (eds), Eucla basement stratigraphic drilling results release workshop: extended abstracts. Geological Survey of Western Australia. pp 41-51

Smithies RH, Howard HM, Evins PM, Kirkland CL, Kelsey DE, Hand M, Wingate MTD, Collins AS, Belousova E (2011) High-temperature granite magmatism, crust-mantle interaction and the mesoproterozoic intracontinental evolution of the musgrave province, central australia. J Petrol 52:931-958. arXiv:http://petrology.oxfordjournals.org/conte nt/52/5/931.full.pdf+html

Smithies RH, Howard HM, Kirkland CL, Korhonen FJ, Medlin CC, Maier WD, de Gromard RQ, Wingate MTD (2015d) Piggy-back supervolcanoes-longlived, voluminous, juvenile rhyolite volcanism in mesoproterozoic central australia. J Petrol 56:735-763. https://doi.org/10.1093/petro logy/egv015

Smits R, Collins W, Hand M, Dutch R, Payne J (2014) A Proterozoic Wilson cycle identified by $\mathrm{Hf}$ isotopes in central Australia: Implications for the assembly of Proterozoic Australia and Rodinia. Geology 42:231-234. http://geology.gsapubs.org/content/42/3/231.abstract, https://doi. org/10.1130/G35112.1. arXiv: http://geology.gsapubs.org/conte nt/42/3/231.full.pdf+html

Spaggiari C, Smithies R, Wingate M, Kirkland C, England R (2016) Exposing the Eucla basement: what separates the Albany-Fraser Orogen and the Gawler Craton?. In: GSWA 2016 extended abstracts: promoting the prospectivity of Western Australia. Geological Survey of Western Australi,. pp 36-41

Spratt J, Dentith M, Evans S, Spaggiari C, Gessner K, Tyler I (2014) Magnetotelluric survey across the Albany-Fraser Orogen and adjacent Yilgarn Craton, southwestern Australia. In: Spaggiari C, Tyler I (eds) Albany-Fraser Orogen seismic and MT workshop 2014, extended abstracts. Geological Survey of Western Australia. pp. 7-11

Thiel S (2017) Electromagnetic monitoring of hydraulic fracturing: relationship to permeability, seismicity, and stress. Surv Geophys. https://doi. org/10.1007/s10712-017-9426-2

Thiel S, Dentith M, Wise T, Duan J, Spratt J, Spaggiari C, Pawley JM, Dutch R, Gessner K, Smithies H, Doublier MP (2016a) Linking Western and South Australia - insights from magnetotelluric profiling. In: Australian Earth Sciences Convention - Abstracts. Geological Society of Australia

Thiel S, Heinson G (2010) Crustal imaging of a mobile belt using magnetotellurics: an example of the Fowler Domain in South Australia. J Geophys Res 115:B06102

Thiel S, Heinson G (2013) Electrical conductors in Archean mantle-result of plume interaction? Geophys Res Lett 40:2947-2952

Thiel S, Reid A, Heinson G, Robertson K (2018) Mapping and characterizing lithosphere discontinuities: examples of southern Australia using AusLAMP MT. In: 24th EM Induction Workshop, Helsingor, Denmark

Thiel S, Soeffky P, Krieger L, Regenauer-Lieb K, Peacock J, Heinson G (2016b) Conductivity response to intraplate deformation: evidence for metamorphic devolatilization and crustal-scale fluid focusing. Geophys Res Lett 43:11236-11244

Unsworth M (2010) Magnetotelluric studies of active continent-continent collisions. Surv Geophys 31:137-161. https://doi.org/10.1007/s1071 2-009-9086-y

Wade B, Barovich K, Hand M, Scrimgeour I, Close D (2006) Evidence for early mesoproterozoic arc magmatism in the Musgrave Block, Central Australia: implications for Proterozoic Crustal Growth and Tectonic Reconstructions of Australia. J Geol 114:43-63
Wade B, Kelsey D, Hand M, Barovich K (2008) The Musgrave Province: stitching North, West and South Australia. Precambrian Res 166:370-386

Walter M, Veevers J, Calver C, Grey K (1995) Neoproterozoic stratigraphy of the centralian superbasin, Australia. Precambrian Res 73:173-195. https:// doi.org/10.1016/0301-9268(94)00077-5

Wannamaker PE, Caldwell TG, Jiracek GR, Maris V, Hill GJ, Ogawa Y, Bibby HM, Bennie SL, Heise W (2009) Fluid and deformation regime of an advancing subduction system at Marlborough, New Zealand. Nature 460:733-736. https://doi.org/10.1038/nature08204

Werner M, Dutch R, Pawley M, Krapf C (2014) Mafic intrusions in the East Musgraves: new geochemical data set available now!. Unlocking SA's Mineral Wealth Technical Forum. Department for Manufacturing, Innovation, Trade, Resources and Energy, Adelaide, South Australia, pp $37-40$

Werner M, Dutch R, Pawley M, Krapf C (2018) Amata Dolerite, Musgrave Province: connections to Neoproterozoic mantle plume magmatism within Rodinia. MESA J 87(34-45):2

Wessel P, Smith WHF, Scharroo R, Luis J, Wobbe F (2013) Generic mapping tools: improved version released, Eos. Trans Am Geophys Union 94:409-410. https://doi.org/10.1002/2013eo450001

Wingate M, Kirkland C, Spaggiari C, Smithies R (2015a) U-Pb geochronology of the Forrest Zone of the Coompana Province. In: Spaggiari C, Smithies $R$ (eds), Eucla basement stratigraphic drilling results release workshop: extended abstracts. Geological Survey of Western Australia. pp 14-16

Wingate M, Kirkland C, Spaggiari C, Smithies R (2015b) U-Pb geochronology of the Madura Province. In: Spaggiari C, Smithies R (eds), Eucla basement stratigraphic drilling results release workshop: extended abstracts. Geological Survey of Western Australia. pp 37-40

Wingate MD, Campbell IH, Compston W, Gibson GM (1998) Ion microprobe $\mathrm{U}$-Pb ages for Neoproterozoic basaltic magmatism in south-central Australia and implications for the breakup of Rodinia. Precambrian Res 87:135-159

Wise T, Thiel S (2020) Proterozoic tectonothermal processes imaged with magnetotellurics and seismic reflection in southern Australia. Geosci Front 11:885-893. https://doi.org/10.1016/j.gsf.2019.09.006

Wong BL, Morrissey LJ, Hand M, Fields CE, Kelsey DE (2015) Grenvillianaged reworking of late paleoproterozoic crust of the southern north australian craton, central australia: Implications for the assembly of mesoproterozoic australia. Precambrian Res 270:100-123. https://doi. org/10.1016/j.precamres.2015.09.001

Xing Y, Etschmann B, Liu W, Mei Y, Shvarov Y, Testemale D, Tomkins A, Brugger J (2019) The role of fluorine in hydrothermal mobilization and transportation of $\mathrm{Fe}, \mathrm{U}$ and REE and the formation of IOCG deposits. Chem Geol 504:158-176. https://doi.org/10.1016/j.chemgeo.2018.11.008

Yang B, Egbert GD, Kelbert A, Meqbel NM (2015) Three-dimensional electrical resistivity of the north-central USA from earthscope long period magnetotelluric data. Earth Planet Sci Lett 422:87-93. https://doi. org/10.1016/j.epsl.2015.04.006

Zhao J, McCulloch MT, Korsch RJ (1994) Characterisation of a plume-related $\sim 800$ ma magmatic event and its implications for basin formation in central-southern Australia. Earth Planet Sci Lett 121:349-367. https:// doi.org/10.1016/0012-821x(94)90077-9

\section{Publisher's Note}

Springer Nature remains neutral with regard to jurisdictional claims in published maps and institutional affiliations. 